\title{
Paleohydrogeology of the Karstic System of Fuentetoba Spring (Soria, Spain): An Interdisciplinary Approach
}

\author{
Eugenio Sanz Pérez, Cristina Fonolla (D), Ignacio Menéndez Pidal * (D) and Pablo Rosas Rodriguez \\ Laboratorio de Geología, Departamento de Ingeniería y Morfología del Terreno, \\ Universidad Politécnica de Madrid, 28040 Madrid, Spain; eugenio.sanz@upm.es (E.S.P.); \\ cristina.fonolla@upm.es (C.F.); pablo.rosasrodrigo@gmail.com (P.R.R.) \\ * Correspondence: ignacio.menendezpidal@upm.es
}

check for updates

Citation: Sanz Pérez, E.; Fonolla, C.; Menéndez Pidal, I.; Rosas Rodriguez, P. Paleohydrogeology of the Karstic System of Fuentetoba Spring (Soria, Spain): An Interdisciplinary Approach. Sustainability 2021, 13, 7236. https://doi.org/10.3390/ su13137236

Academic Editors: Robert Brinkmann and Leslie North

Received: 19 May 2021

Accepted: 22 June 2021

Published: 28 June 2021

Publisher's Note: MDPI stays neutral with regard to jurisdictional claims in published maps and institutional affiliations.

Copyright: (C) 2021 by the authors Licensee MDPI, Basel, Switzerland. This article is an open access article distributed under the terms and conditions of the Creative Commons Attribution (CC BY) license (https:/ / creativecommons.org/licenses/by/ $4.0 /)$.
Abstract: As a preliminary phase in the conservation and sustainable management of a karst system in Fuentetoba, Soria, Spain, an interdisciplinary study was carried out to determine its hydrogeological evolution. The hydrogeological history of this aquifer system began during the late Miocene, where discharges were driven by paleo-emergences in the moor, and associated conduits were developed under phreatic (or vadose) conditions-for example, the upper syngenetic galleries in the main known karst cave (Majada del Cura cave). Later on, the nearby karstic massifs, a general flattening of the relief, occurred during the Quaternary Period, during which the karstic base level had been in decline. The aquifer flow was then derived and modified towards the Fuentetoba spring from the earliest stages through the galleries of the aforementioned cave. The observations made in this cave indicate the existence of a unique type of hydrogeological organization. The hypogean network is the result of the excavation of the same water flow that has been entrenching and abandoning the vadose regimen toward the free regimen. The dating of the tuffaceous buildings, associated with the emergences, indicates that since almost the Middle Pleistocene, flow lines have converged in the Fuentetoba spring, inducing a high grade of karstification in the saturated zone of the syncline basin. Moreover, a major drainage conduit was developed by dissolution. During the late Upper Pleistocene, an essential component of the groundwater flow had been derived towards the source of the Mazos River spring. Tufa and paleogour datings in caves indicate that the aquifer has undergone different climatic stages during the latest Quaternary and, therefore, different feeding and recharge processes. These tufas and paleogours are interrelated as well, as they are associated with the warm stages during the most recent Quaternary, according to the regional context, when there was less natural recharge. The simulation of the springs' flow enabled an approximate quantification of the variation in the aquifer's hydraulic balance during the different climatic stages. For example, during the last glaciation, the natural recharge was impacted by snowmelt and increased by $160 \%$.

Keywords: karst system; climate change; hydrogeological evolution; speleogenesis; natural recharge and paleoclimates; Iberian Range

\section{Introduction}

The karst system of Fuentetoba is situated in the easternmost region of the Sierra de Cabrejas (Iberian Range, Spain). The karst constitutes a $29 \mathrm{~km}^{2}$ aquifer, which drains via the Fuentetoba spring (220 L/s average flow) and by the Mazos River spring (50 L/s). Fuentetoba is an impressive spring that rises hanging on the mid-slope of the hill at an altitude of $1140 \mathrm{~m}$, dropping in the form of a $20 \mathrm{~m}$ waterfall from the calcareous tufas associated with the spring, giving way to the Golmayo River (Figure 1).

The Fuentetoba karst system represents an excellent example of an unconfined karst aquifer and is accurately geometrically defined; it was possible to obtain in situ observations in the active and abandoned conduits in the unsaturated zone, i.e., inside the stream caves, using conventional speleology and speleodiving methods. Moreover, it was possible to 
access an important submerged phreatic conduit in the saturated zone by speleodiving. Both the phreatic galleries of the Fuentetoba spring and the hypogean river in the cave are associated with Fuentetoba, which reflects the nature of the cave's interior, albeit only partially. Exploration by local speleodiving clubs (see Acknowledgments) of these two apparently independent cavities, which both converge at the Fuentetoba spring, presents the possibility of clarifying the current and past drainage of this karst system despite the fact that these are fragments of conduit networks from a subterranean drainage system that is supposed to be wider. This drainage network was utilized to design a potential spring regulation system [1].

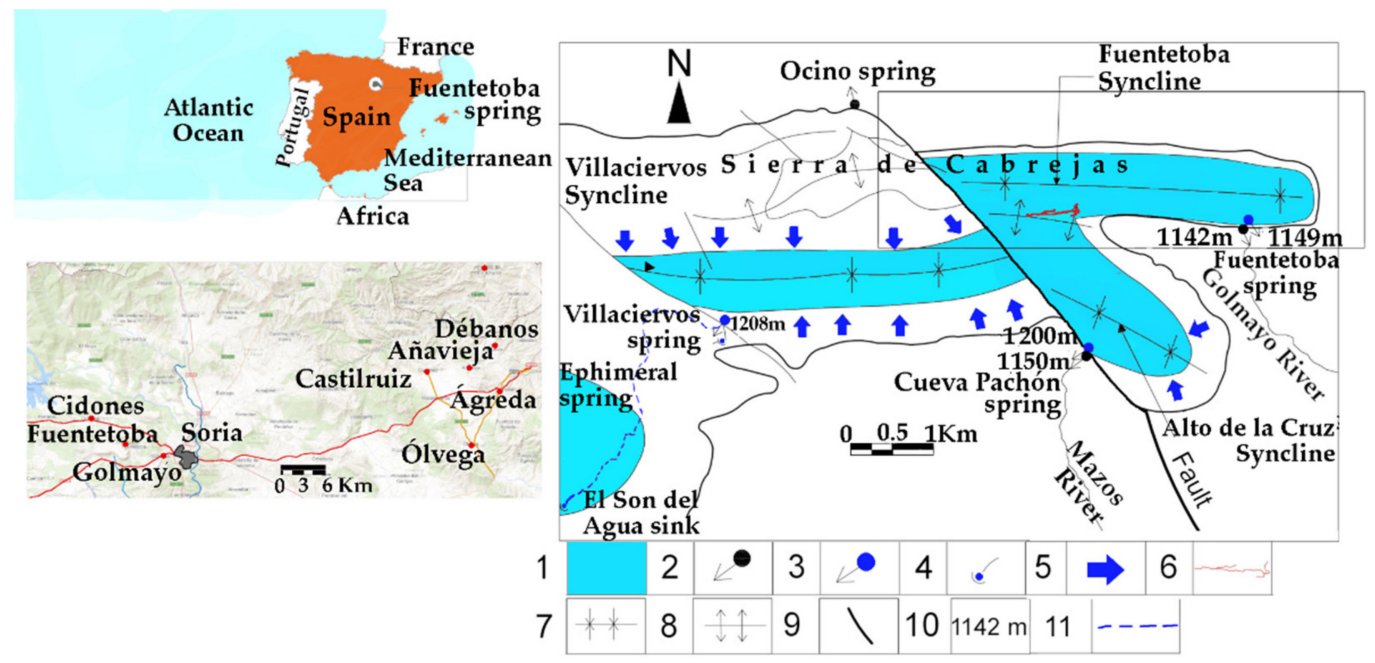

Figure 1. Location of study area. Karst system of Fuentetoba spring and source of Mazos river. 1, permanently saturated zone; 2 , perennial spring; 3 , intermittent spring; 4 , sink; 5 , groundwater flow in saturation zone periphery; 6 , the Majada del Cura cave; 7 , syncline; 8 , anticline; 9, limestone-marl contact outcrop; 10, ground level; 11, Son del Agua stream, which originates from the Villaciervos perennial spring.

In a karst study, sufficient knowledge of the actual local conditions (sometimes with consideration of the aquifer's hydrogeomorphology) is essential because a karst can be the result of different geological contexts and can also be subjected to different conditions of storage and flow. Some efforts have been made to incorporate geomorphological and hydrological investigations into karst studies [2,3]. In many cases, groundwater flow is constrained by the presence of ancient endokarst forms. Usually, inherited phreatic karstic forms have developed a network of passages and galleries that nowadays is active in both saturated and unsaturated zones. The karst processes have developed an organized conduit network, comparable to the organization of flow in a surface river [4].

It could be said that the necessity of taking into consideration the hydrogeomorphological features in order to understand the behavior of an existing karst system is, perhaps, unique to karst studies with respect to other fields of hydrogeology [5]. Moreover, a cavern has very limited value unless it is associated with the karst circulation in a specific area. Hydrology and speleology are inextricably linked subjects, and one cannot be understood without the other [6,7]. Therefore, speleogenesis study, along with an understanding of regional cave systems development, would promote better knowledge of karstic aquifer evolution [8].

This evolution is influenced to a great extent by the external geomorphological history of the region, which more often conditions the lowering of the spring level; consequently, the depression of the karstic base level, due to karstification, is extended in depth below the spring levels as a consequence of the spreading streamlines [9]. Geologically, karstic processes occur quickly; generally, a conduit network could be developed below $50 \mathrm{ky}$, as is estimated by some authors [10-12]. Therefore, knowledge of the geomorphological history, 
as well as the lowering of the karstic base level and the karstification span, can provide qualitative information about the development grade of the system and the enlargement of the storage capacity due to the increase in porosity.

Prior investigations of the Fuentetoba aquifer's evolution have included a morphosedimentary record of both the exterior (tufas) and interior (speleothems) components of the karst system since they are paleohydrological and paleoclimatic controls. Calcareous tufas establish a sedimentary record with paleoclimatic potential because, in general, they are indicators of the warm interglacial conditions during the Quaternary Period [13]. Moreover, the origin of calcareous tufas could be associated with both interior and exterior karstic morphology along with speleothems from the same karstic system or those nearby [14]. In the Iberian Range, tufa developments are common and are interrelated with the fluvial network and with the karstic springs, which experienced greater growth during the warm periods [15]. Moreover, tufas can provide information about the previous reaction of the local flows in an aquifer during past climates; they can also confirm the situation of some karstic aquifers' ancient discharges [16]. With regard to the speleothems, the paleogours' barriers in this system frequently highlight outcrops in the steps of the ancient groundwater flows in caves, where the water agitation enabled calcic carbonate precipitation.

On the other hand, as is known, natural recharge is the component of the hydrologic cycle that, at the time of analysis, has been most influenced by climate changes. One means of studying past recharge variation is via precipitation-runoff recharge mathematic models, which are calibrated with up-to-date hydrological series. In these models, different precipitation and temperature data of previous scenarios are contrasted. These models generate historical hydrological series for the Little Ice Age, during the last glaciation, etc. This is possible if contour conditions and other factors associated with the recharge have not been substantially altered (land use, vegetation, etc.). For this reason, and although dependent on particular cases, future analysis cannot be carried out beyond the Holocene and Upper Pleistocene. The Fuentetoba system constitutes, in this sense, a worthy pilot aquifer with a well-defined natural regime. In addition, it is highly representative of karstic aquifers from this area of the Iberian Range, whose hygrogram has been simulated for a 20 -year series [17].

The aims of this article are as follows:

- To determine the main characteristics of the paleohydrological evolution and speleogenesis of the karstic system during the late Tertiary and Quaternary and to demonstrate how the karst's evolution affects the past and present aquifer hydrodynamics.

- To build a chronological preliminary calcareous tufa frame associated with the springs in addition to the representative speleothems of the cave network, in order to evaluate the paleohydrological and paleoclimatic significance of the obtained results; the article aims also to connect the tufa accumulations with speleothems (paleogours) within the same aquifer.

- To use a precipitation-runoff mathematical model to simulate the Fuentetoba spring [17], in order to study the probable past behavior of the karst system in different climatic conditions, as quantified, for example, by the natural recharge variation.

\section{Methodology}

According to the specific characteristics of this location and the available information resources, the following research methods were applied and combined.

Firstly, a three-kilometer area of a direct network of galleries and their morphosedimentary deposits was explored by traditional speleology and speleodiving of actual active conduits. Both the epiphreatic (vadose) zone and saturated zone were surveyed, so that the karstic system's functional approach and many system particularities could be better understood.

A geomorphological and hydrogeological study of the spring's calcareous tufas was conducted in order to reconstruct the evolution of the karst systems. Furthermore, a surface cartographic survey allowed us to differentiate tufa outcrops from the Fuentetoba 
and Mazos River springs (the only two points with tufas surrounding the aquifer). The Fuentetoba spring area has two tufa masses hanging on the slope, approximately at the same altitude and located $250 \mathrm{~m}$ apart: La Toba (tufa) and La Monjía (abbey). Six distinctive samples were gathered in the tufas of these two springs (Table 1, N. 3-A, 4, 7, 10.A, 11.B). Moreover, during surveys and speleological studies, two paleogour levels were discovered, located at different heights in the hypogean river gallery, where samples were acquired from paleogours from the middle and higher levels (N1 and N8 in Table 1). Furthermore, a speleothem was collected (stalagmite N 9 in Table 1), although stalactites in this cave are few.

Table 1. Results of the dating ranges of the speleothem samples of the Majada del Cura cave and tufas from FuentetobaMazos, Añamaza, Ágreda and Vozmediano areas.

\begin{tabular}{|c|c|c|c|}
\hline Place & Name & Nominal Date (Years bp) & Method \\
\hline \multirow{5}{*}{ The Majada del Cura Cave } & N1 Middle Gour & $188,808+17,060 /-14,853$ & Th-230/U-234 \\
\hline & N2 Bones (c) & - & - \\
\hline & N7 Clay ${ }^{(\mathrm{c})}$ & - & - \\
\hline & N8 High Gour & 350 & Th-230/U-234 \\
\hline & N 9 Stalagmite & $6978+568 /-565$ & Th-230/U-234 \\
\hline \multirow{4}{*}{ Spring's tufa } & N4 La Monjía & $335,683+98,854 /-52,534$ & Th-230/U-234 \\
\hline & 3-A Mazos River (a) & $38,858+1660 /-1635$ & Th-230/U-234 \\
\hline & N 10-A Fuentetoba ${ }^{(b)}$ & $252,304+70,511 /-42,615$ & Th-230/U-234 \\
\hline & N 11-B Pachón Cave ${ }^{\text {(c) }}$ & - & - \\
\hline \multirow{2}{*}{ Añamaza's tufa } & 1 & $225,000+25,000 /-20,000$ & $\mathrm{U} / \mathrm{Th}$ \\
\hline & 2 & $75,000+12,500 /-12,500$ & $\mathrm{U} / \mathrm{Th}$ \\
\hline \multirow{3}{*}{ Ágreda's tufa } & Dam & $240,034+19,920 /-16,963$ & $\mathrm{U} / \mathrm{Th}$ \\
\hline & Railway station & $180,108+9365 /-8754$ & $\mathrm{U} / \mathrm{Th}$ \\
\hline & Keyles River & $40,350 \pm 1950$ & $\mathrm{C}-14$ \\
\hline Calcareous tufa terrace & Vozmediano spring & $19,159+947 /-950$ & Th-230/U-234 \\
\hline
\end{tabular}

(a) Indicative, contaminated by Th 232; (b) Slightly contaminated by Th 232; (c) Unable to date due to high residue levels.

Aside from these samples, many others were collected nearby (Ágreda, Añavieja and Vozmediano, $40 \mathrm{~km}$ southwards at the same altitude and climate), including six samples of tufa terraces belonging to some earlier lakes of the tufa barrier, with the objective of increasing the published data [18] and completing the picture of the regional paleoclimate.

All the samples were dated with the rates of decay of radioactive isotopes of uranium/thorium (U/Th) at the "Jaime Almera" Institute (Earth Sciences Institute), C.S.I.C. by means of using ICP-MS [19].

To determine the system's speleogenesis and to propose the evolution of the karst aquifer during the late Tertiary and Quaternary, the conceptual model of the hydrological performance aquifer $[17,20,21]$ was related to the regional external geomorphology, the external altitudinal layout of caves, springs, the characteristics of active and abandoned conduits, as well as the dating of spring tufas and cave sediments.

Since contour conditions and land use have not substantially changed in this aquifer during the recent Quaternary, a precipitation-runoff model CREC (Centre de Recherches et d'Essais de Chatou) was applied [17] to past climates (last glaciation, interglaciation, $\mathrm{PEH}$ ) and to different future backgrounds to quantify the hydrologic balance variation. The integration of the results with the data available and the actual conceptual hydrological model allowed the estimation of the past functioning of the hydrological system.

\section{Area Description}

\subsection{Climate and Vegetation}

Nowadays, this area has a Mediterranean climate with relatively cold winters, and the average annual precipitation in this sector of the Sierra de Cabrejas is $574 \mathrm{~mm}$, with its maximum occurring in spring; the spatial distribution of the precipitation in this plateau is 
very uniform, and in winter, it is common to observe snow precipitation. The harsh continental climatic conditions of this zone, in addition to the soil poverty, are not suitable for crops. Despite this, the high infiltration capacity, as well as the low water retention due to the presence of the karst, provides the plateau with its acute aridity and has sheltered the most extensive Spanish juniper (sabina alvar, Juniperus thurifera) forest in Europe, which is one of the trees inherited from the Tertiary and is more resistant to the aforementioned climatic conditions. This tree withstands intense cold and heat and extended drought. In fact, Spanish juniper occupies niches where other species cannot subsist. Sometimes, it shares its territory with holm oak (Quercus ilex subs.) and other less representative species-for example, in Pico Frentes, where the holm oak abundance made charcoal production one of the most important activities in the Medieval and Modern Ages. It also gives its name to a nearby village, Carbonera de Pico Frentes. As a result of the stony floor, the development of other activities was not allowed. Only sheep and goat shepherding were permitted in the past in the Spanish juniper forest (sabinar), the open forest where vast thymus-grassland surfaces for grazing remain.

\subsection{External Geomorphological Characteristics}

The Sierra of Cabrejas was affected by a prolonged denudation epoch that took place along the Upper Neogene, where generalized flattening and levelling occurred at an altitude of $1240 \mathrm{~m}$, although it sloped south slightly. This erosional surface could be comparable with the level SE2 from [22], in the Middle Miocene, which is equivalent to the Intra-Miocene Erosion Surface (IES) from [23]. On the edges, inselbergs or residual hills emerge, where summits rise to an altitude of nearly $1400 \mathrm{~m}$. Furthermore, between altitudes of $1160 \mathrm{~m}$ and $1170 \mathrm{~m}$, another high plateau could be identified (Villaciervos high plateau) $[23,24]$. Laterally (during the Pliocene and Quaternary), over the IES, there have been previously developed doline fields, some uvalas, karrens and an incipient, shallow and relict drainage network, which remains carved into the rock in some areas. Nowadays, this river network runs as a dry river with a high recharge capacity. The following erosive phases triggered the flattening of the relief in the nearby calcareous massif to an altitude of 1030-1000 m, which is the altitude of the Douro River in the north of the Sierra de Cabrejas. These later erosive phases were manifested as follows (from highest to lowest): ante-fluvial pediplain (1070 m), Douro's medium terrace (1037-1042 m), Douro's lower terrace (1020-1026 m), Douro River floodplain (approximately 1017 m) [24,25].

\subsection{The Karstic System}

The hydrostratigraphic level in this system is formed by an Upper Cretaceous calcareous massif with a thickness of $220 \mathrm{~m}$. It lies upon low permeable Cenomanian-Turonian marls [26]. Sandstones and lutites from Weald and Utrillas facies (that underlie the marls) are also considered low-medium impervious. Moreover, the karst massif presents a welldefined folded geometry, which has resulted in the aquifers being situated chiefly in three hydraulically connected synclines (Figure 1). Groundwater flows through the bottom of the syncline bottom at a large scale, whereas at a small scale, groundwater flows to the Fuentetoba spring $(210 \mathrm{~L} / \mathrm{s})$ through subterranean currents, as well as through the Mazos River spring (50 L/s), with other minor discharges appearing in high waters.

This unconfined aquifer's limits are quite precise, since the calcareous massif rests on the top, similar to a plateau, and the low permeable Cenomanian-Turonian marl outcrops on all its hillsides, except on the westernmost side, where limestones merge and are seamlessly linked with the neighboring aquifer of the Fuentona de Muriel spring (1000 L/s flow rate) [27].

This limit disappears to the west. However, the aquifer is well-defined by a central hydrogeologic relative barrier, where its impermeable bedrock is elevated by a fault effect, which forms a physical underground divide with the former aquifer, which is laterally connected (this has been confirmed by chemical tracers) [17].

The whole aquifer is recharged autogenously from the diffuse recharge from rainwater and snowmelt. The recharge is supported by the presence of a plateau with a poorly defined superficial drainage network. 
The western aquifer has a plunging syncline structure (Villaciervos syncline) that faces east and conditions the flow convergence as well as water storage in its core. The groundwater flow is driven eastwards, and the main flow is driven to the Fuentetoba syncline after passing the Ocenilla Fault via the Majada del Cura Cave gallery (as well as other caves), following the limestone-marl contacts to the Fuentetoba spring (Figure 1) [17]. Furthermore, the water stored in the Alto de la Cruz syncline (Mount of the Cross) is directed toward Fuentetoba, saving the anticline axis threshold that separates the two folds; therefore, only the meridional side of this fold should feed the Pachón Cave spring.

Hydrograph analysis and the speleological explorations of the spring indicate a system with a highly variable regimen (between 8 and $3400 \mathrm{~L} / \mathrm{s}$ ), as well as an attenuated natural regulatory capacity, due to the predominant current with a non-Darcian turbulent flow behavior, which passes through an underground torrent in the vadose zone. Moreover, it flows across karstic conduits in the phreatic and epiphreatic zone, as revealed by the speleological explorations. It has the characteristics of a typical karstic aquifer that has a huge recharge capacity and a short residence time $[17,20]$.

Thanks to the hydrograph simulation of these springs by a precipitation-runoff mathematical model (CREC), a detailed quantification of the mean hydraulic balance was carried out for a 20 -year series: rainfall- $16.86 \mathrm{hm}^{3}$, natural recharge- $8.35 \mathrm{hm}^{3}(49.53 \%)$, ET-8.50 $\mathrm{hm}^{3}$ (50.41\%) (evapotranspiration), groundwater pumping-0.01 $\mathrm{hm}^{3}(0.06 \%)$, runoff $-0 \mathrm{hm}^{3}$, groundwater transfer to other aquifers- $0 \mathrm{hm}^{3}$ [17].

\section{Results}

4.1. Paleohydrogeological Information Provided by the Endokarst: The Majada del Cura Cave and Fuentetoba Spring's Trop-Plein Syphon

The karst system presents numerous tiny cavities, potholes and caves; among these, two cavities are notable and could provide information about the karst's epiphreatic and phreatic zones. Furthermore, the Majada del Cura cave is east-west-oriented and is $3 \mathrm{~km}$ in length. The lower galleries are active. A cave map is provided in Figure 2, which includes information about the sedimentary deposits conserved within the cave. In addition, the first gallery level is hanging in this cave; it is also fossilized, is mostly horizontal and has vast dimensions. This level is placed $-20 \mathrm{~m}$ below the entrance at an altitude of $1220 \mathrm{~m}$. Moreover, the second level of galleries (actives) is connected by the inclined galleries of the first level. Here, the current vadose circulation is represented by an underground river whose path moves towards the outflow in Fuentetoba, with a succession of waterfalls and rapids interconnected by longer and shorter stretches in free circulation but with many local syphons.

The second level of galleries could be located at a height of between $-30 \mathrm{~m}$ (western) and $-70 \mathrm{~m}$ (eastern) from the entrance. The other is a submerged cave, a pressure flow tube associated with a trop-plein (overflow) of the Fuentetoba spring (intermittent spring). It is N-S-oriented, is $400 \mathrm{~m}$ in length and is developed through the vadose zone of the syncline in the aquifer, reaching a depth of $-41 \mathrm{~m}$ with respect to the altitude of the spring.

\subsubsection{The Paleohydrological Information Provided by the Upper Galleries}

The upper gallery is extraordinarily horizontal, and, in its cross-section, marked stratigraphic control was observed, demonstrating that the ceilings of the galleries are northdipping flat layers. In some cases, however, the cylindrical sections remain. Moreover, the lateral gallery entrance, which is closed to the surface, has a lightly inclined, tube-shaped, cylindrical cross-section on its walls and has dissolution scallop marks. It appears that it was a former paleoconduit from an old emergence. There are other minor remains of phreatic conditions, prior to the Quaternary, such as scallops on the walls and solution cupolas on the ceilings, and solution pockets that are not connected to the exterior, which were generated by dissolution from below to above, because they can be created by condensation corrosion in vadose conditions [2]. 


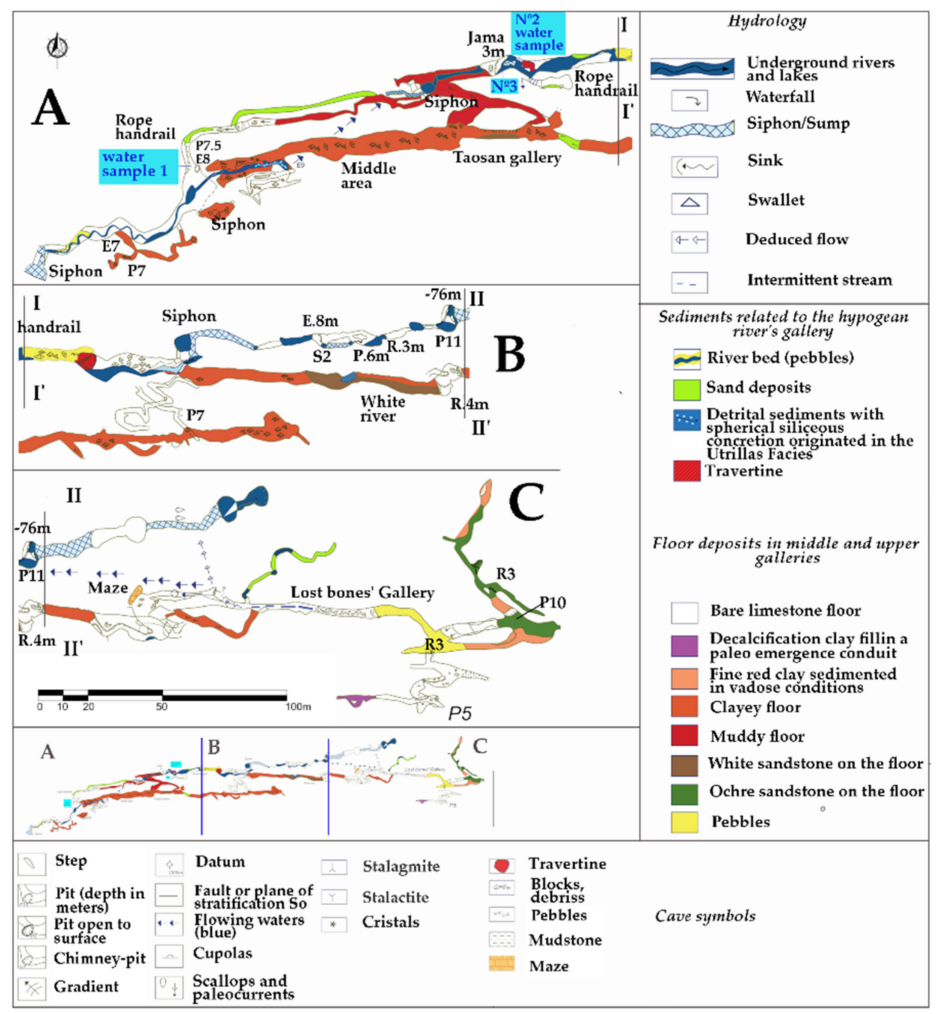

(a)
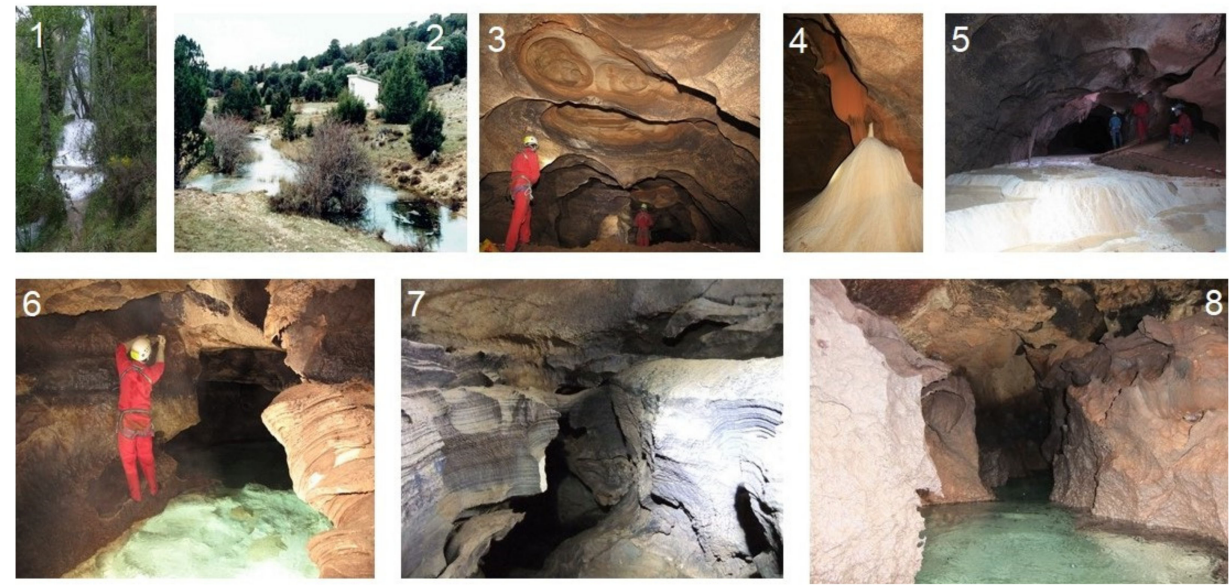

(b)

Figure 2. (a) Majada del Cura cave map (spreading in A, B, C and D sections, see key map in the figure), with emphasis on the floor deposits in the middle and upper galleries: 1. Bare limestone floor, 2. Decalcification clay filling a paleo emergence conduit, 3. Fine red clay sedimented in vadose conditions, 4 . Clayey floor, 5 . Muddy floor, 6 . White sandstone on the floor, 7 . Ochre sandstone on the floor, 8. Pebbles. Sediments related to the hypogean river's gallery: 9. Riverbed (pebbles), 10. Sand deposits, 11. Detrital sediments with spherical siliceous concretions originated in the Utrillas Facies, 12. Travertine. Hydrology: 13. Underground rivers and lakes, 14. Waterfall, 15. Syphon/Sump, 16. Sink, 17. Swallet, 18. Deduced flow, 19. Intermittent stream. Cave symbols: 20. Step, 21. Pit (depth in meters), 22. Pit open to surface (entrance), 23. Chimney pit, 24. Gradient, 25. Datum, 26. Fault or planes of stratification SO, 27. Flowing waters (blue), 28. Cupolas, 29. Scallops (Syphon) and paleocurrent, 30. Stalagmite, 31. Stalactite, 32. Crystals, 33. Travertine, 34. Blocks, debris, 35. Pebbles, 36. Mudstone, 37. Maze. (b) 1. Fuentetoba spring waterfall. 2. Villaciervos trop-plein (Figure 1) in high waters. 3. Upper Gallery at Cueva de la Majada del Cura: inverse erosion domes on the ceiling, on the ground, clays. 4. Upper Gallery: Pleistocene speleothems. 5. Upper Gallery. Current microgours or rimstones. 6. Underground river. On the right wall and above, hanging paleogour speleothems. 7. Detail of paleogour speleothems (sample for dating) 8. Subterranean river embedded. Above, hanging yellowish paleogours. 9. Rapids in the subterranean torrent. Hanging speleothems from eroded paleogours. 10. Small lake in the underground river. (Photos courtesy of Terrasub Deportivo Espeleología). 
A general characteristic of all sections is that the soil is covered by a flat fill of very fine and homogeneous red clay, without intercalations of precipitate calcite layers or other types.

Although the change to a free regime would produce erosion of these clayed deposits, nowadays, thick beds still remain in passages, and, in lateral chambers, the clay deposits have a thickness of over $4 \mathrm{~m}$.

\subsubsection{The Paleohydrological Information Provided by the Active Lower Gallery}

The most characteristic section of the active gallery of this cave corresponds to a wider upper part with initially phreatic conditions. This gallery was deepened again by the river, forming a narrow, meandering canyon. This reactivation indicates its evolution from a phreatic regimen to a vadose one.

The current overflow hydrology of the hypogean river is reflected by the occasional presence of gravel terraces with sand deposits. They are established at a height of $1 \mathrm{~m}$ on the modern riverbed. Some of these sandy sediments have been eroded by the hypogean river, upstream of the Utrillas facies, close to the Ocenilla Fault [21].

As previously mentioned, waterfalls, rapids, some small lakes and several syphons abound in the hypogean river. In the past, each slope break and waterfall drop formed rimstone pools (gours), which yielded a lacustrine phase with a sequence of lakes, one after another, where the river flow was precarious. Moreover, the small paleolevels (sometimes six levels) of the old lakes are indicated by horizontal iron oxide lines on the walls, which indicate the river's successive incision pulses [21], reaching heights of up to $3 \mathrm{~m}$ with respect to the actual riverbed. In the paleogours, two generations of stalagmitic crusts could be identified between two terrace levels located $0.5 \mathrm{~m}$ and $5 \mathrm{~m}$ above the actual riverbed. Furthermore, samples for chronological dating were gathered at both terrace levels.

\subsubsection{Syngenetic Cave Galleries: Fuentetoba Spring Syphon}

The Fuentetoba spring has an associating trop-plein located nearby ( $7 \mathrm{~m}$ above). This is a unique conduit, with a $400 \mathrm{~m}$ length and $20^{\circ}$ dip towards the north. It has an ellipsoidalshaped horizontal section, particularly constant, that has a $2 \mathrm{~m}$-long axis (Figure 3 ). This shaft has a deep phreatic forced flow, and it deepens somewhat into half of the small syncline core's saturated zone. Furthermore, this characteristic permits efficient drainage of this section of the aquifer. This cavity was developed following the direction of the layers dipping into the syncline core. The conduit is empty, but in its lower site, it is filled with some rounded pebbles and the walls have been affected by corrosion, so they are completely carved, with decimeter- to centimeter-sized scallops (the median size is $20 \mathrm{~cm})[20]$.

During high waters, the water level in the gallery increases by $5 \mathrm{~m}$, allowing it to slightly overflow through the entrance. When the spring flow exceeds $2000 \mathrm{~L} / \mathrm{s}$, it functions as a trop-plein, and, as a result, water discharge at the middle slope spring amounts to $50 \mathrm{~L} / \mathrm{s}$ afterward. Overall, it seems that this conduit is used as a secondary drainage route.

\subsection{External Morphology with a Paleogeographic Significance: The Fossil Superficial Drainage Network}

All the above-mentioned geomorphological features, besides the dolines, uvalas and karrenfeld that exist on the IES, have a relict superficial fossil drainage network, which has a shallow arborescent silhouette (less than $10 \mathrm{~m}$ depth) and outline. This is preserved in some areas. In Pico Frentes, these morphologies are conserved, following the maximum gradient in the inclined plane, where they are overrun with small dolines. However, they are spectacularly preserved, with a fresh appearance and without dolines, in the south of the study area, in the north of the Villabuena and Camparañón villages, as a continuation of the IES.

Within the abandoned drainage network, there is a singular greater valley (Valle del arroyo del Son del Agua), which is $40 \mathrm{~m}$ in depth and $3 \mathrm{~km}$ in length on the IES and surrounded by low residual reliefs over $1300 \mathrm{~m}$ in altitude. Downstream, the valley disappears as the stream flow is enclosed by only a few meters by the Villaciervos plain 
(between $1160 \mathrm{~m}-1170 \mathrm{~m}$ ) until it reaches the permanent sink, the Son del Agua (the water sound), where both the water flow and the riverbed disappear (Figure 1). Moreover, this stream seldom flows. It rises in some springs located at an altitude of $1220 \mathrm{~m}$ at the bottom of a small karstic amphitheater at the head of the valley. In addition to the springs, which only appear after severe precipitation during certain winters, they form a creek with a flow of nearly $300-400 \mathrm{~L} / \mathrm{s}$, which only lasts one or two weeks. In addition, the phreatic level is $20 \mathrm{~m}$ below the surface (as inferred from the wells that supply Villaciervos [28]), and only during heavy rains or snow does the water table rise and the spring overflow. However, over the last 40 years, it seems that it has only emerged when the flow has risen above $1000 \mathrm{~L} / \mathrm{s}$ in the Fuentetoba spring [1].

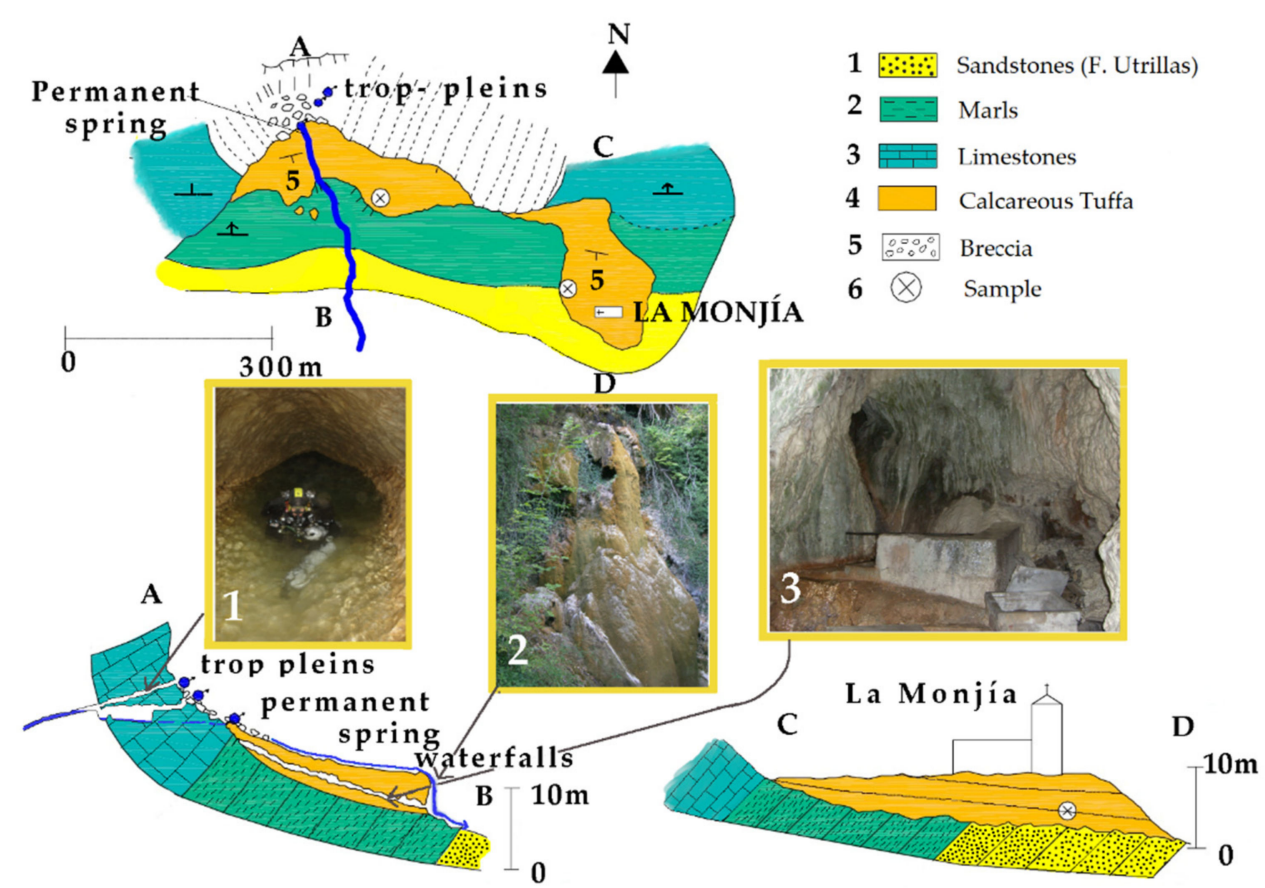

Figure 3. Tufas from the Fuentetoba spring zone and from La Monjía. Above: schematic geomorphological map showing cross sections $\mathrm{AB}$ and $\mathrm{CD}$. Below: geomorphological cross-section $\mathrm{AB}$ of the Fuentetoba spring (left) and cross section CD at La Monjía spring (right). 5. Breccia, 4. Calcareous tufas, 3. Limestones, 2. Marls, 1. Sandstones (Utrillas facies).

\subsection{The Spring's Calcareous Tufas}

\subsubsection{Geological Context}

The calcareous tufas in this aquifer constitute tufa deposits associated with karstic emergence on the Fuentetoba and Pachón Cave slope (the latter is the emergence of the Mazos River).

Fuentetoba area:

In the Fuentetoba area, there are two different zones: the first is associated with the spring and the second is located a few meters eastwards, in La Monjía (monastery), where the monastery's calcareous tufa is located $250 \mathrm{~m}$ east of the Fuentetoba spring's tufa; they are almost connected in the upper part (the ceiling of the tufa deposit is 2-3 $\mathrm{m}$ higher).

There is a huge travertine building that is genetically linked to the karstic emergence of La Toba (Fuentetoba). Moreover, the existence of this hanging spring in the middle of the slope led to the emergence of a cuneiform travertine complex with an inverted triangle form. The frontal talus is vertical, from which a $20 \mathrm{~m}$ waterfall originates. The complex has had a progradation forward and it is, or has been, conditioned by the intense precipitation of calcium carbonate in the waterfall facade or in the active channels, where the water turbulence improved the $\mathrm{CO}_{2}$ degasification. Here, direct chemical precipitation is produced or biologically induced by moss, incrusting algae or bacteria that colonize the 
waterfall, which is always humid, well-oxygenated and with great insolation due to its southern orientation. In terms of the outcrops, it is a massive complex that is constituted by grossly stratified porous and cavernous layers, and the dip follows the abrupt topographic slope. Furthermore, concentric zoning and elongated draperies or curtains associated with the water drop can be seen and reflect the growing rate of bryophyte-cyanophyte association. In addition, foliar patterns frequently occur.

The preserved tufa building is smaller than it was in the past and was connected with La Monjía. Moreover, it has been affected by depositional phenomena such as karstification or slides. Additionally, block slides of giant tufa have partially ruined it. Slides come about mainly when the tufa lays on the sandstones from the Utrillas facies. When the sandstones are saturated with water, they slide, bringing the above tufas with them, as was observed, for example, in the Ocino spring in Cidones (Soria), next to the study area (Figure 1). The inside of the tufa building is partially karstified by the water dissolution of the spring; some caves have been formed in this way.

The tufa deposits in La Monjía have the same geometrical characteristics, volume and lithofacies as La Toba. The former is also a massive complex formed by an ancient emergence, hanging on the slope, which has a cascading shape. In the case of the Toba spring, the tufas are attached to the slope through the stratigraphic contact with the marls and through contact with the Utrillas facies sandstones (Figure 3).

The tufas from the Mazos spring emergence or Pachón Cave:

Here, the lenticular tufa outcrop is stratified, and it dips $10^{\circ}-15^{\circ}$ down the slope (southward) as in Fuentetoba. Furthermore, the tufa has been developed $200 \mathrm{~m}$ from the Mazos creek spring, on the limestone-marl contacts, to the Utrillas facies, with a $20 \mathrm{~m}$ drop and $10 \mathrm{~m}$ thickness. In the tufa, two facies were identified: the lower layer is thinner and more or less stratified, and the upper layer is darker and powdery with various organic matter (Figure 4). In addition, in the southern and lower zone, an accumulation of oncolites was observed, which are fossilized or have protected slope debris from a previous cold period. Contrastingly, in the upper part of the slope, the slope debris partially covers the tufa deposits.

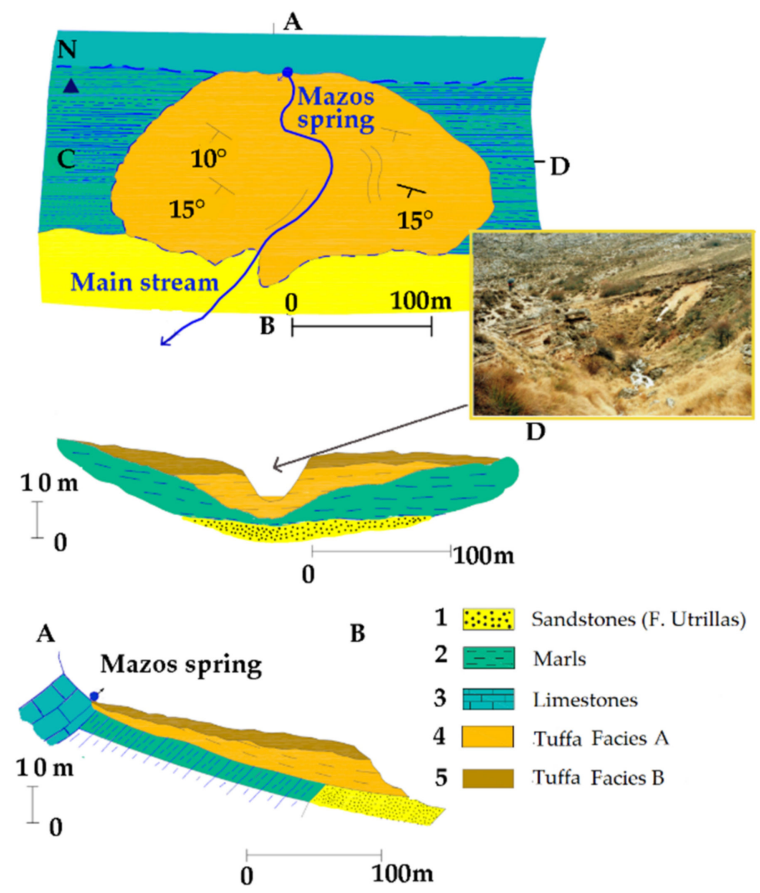

Figure 4. Calcareous tuffs from the Mazos River spring area (Cueva Pachón) Above: schematic geomorphologic map. Below: geomorphological transversal cross-sections (A,B) and longitudinal cross-sections (C,D). 


\subsubsection{Dating of Tufas and Speleothems (Paleogours)}

Fuentetoba karst system.

Table 1 lists the dating rage ( $\mathrm{U}-\mathrm{Th}$ and ${ }^{14} \mathrm{C}$ ) obtained from speleothems corresponding to paleogours from the Majada del Cura cave and to tufas from the Fuentetoba-Mazos River spring area, as well as from the Añamaza and Ágreda zone (Figure 5).

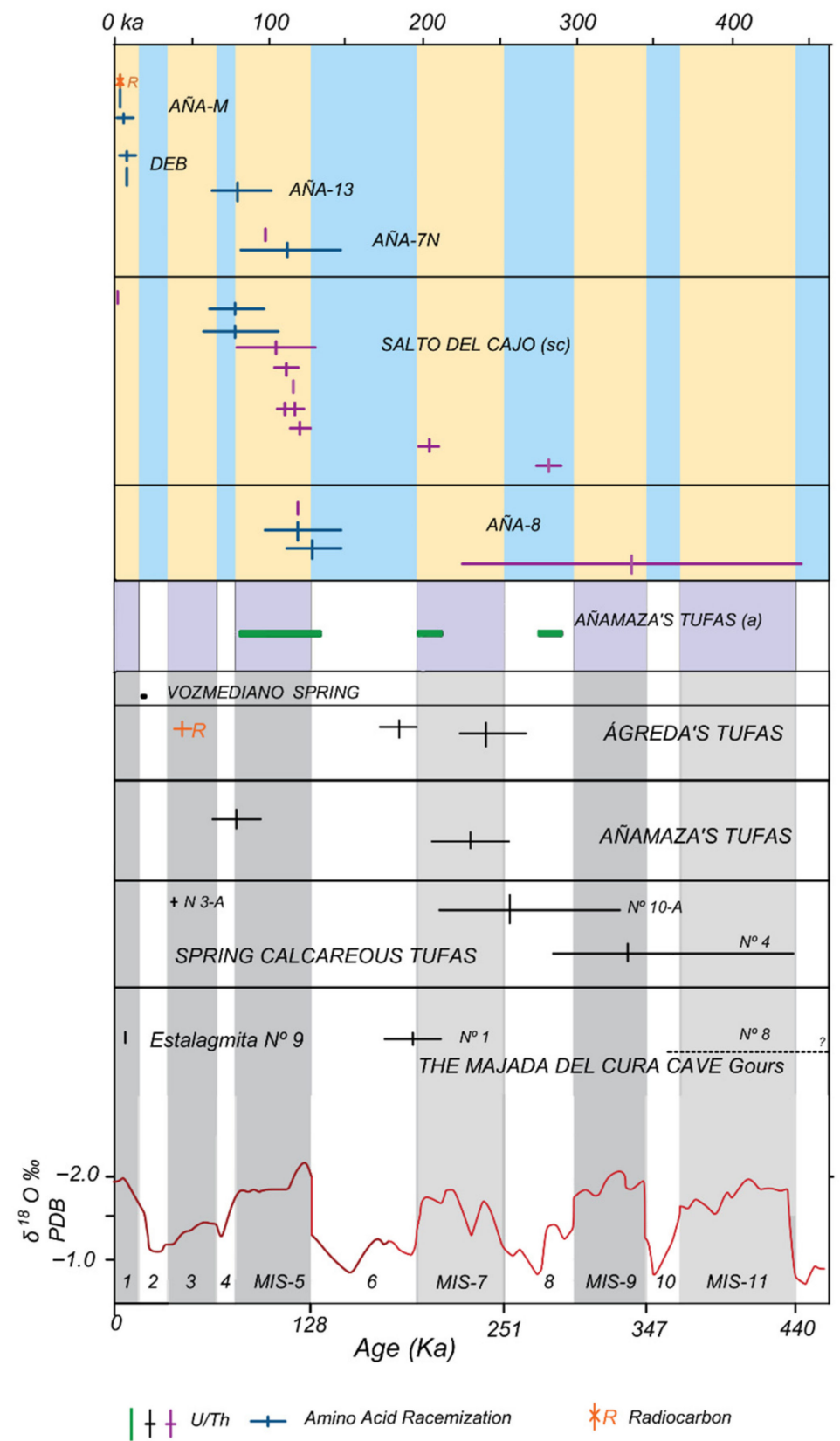

Figure 5. Dating results and analysis of tufa collected in Añamaza tufa, Vozmediano spring and other calcareous tufa springs, and speleothems belonging to gours and a stalagmite in the Majada del Cura Cave. Data from [15] and [18] were added. Samples from [15] have been represente in green. The upper part of the plot includes ANA-8 (blue and cream stripes), which represent calcareous tufa samples collected in Añamaza and Débanos. The red line at the bottom represents the correlation between $\delta 18 \mathrm{O} \%$ and the age of the Pacific core samples described in [29].

U-Th sample dating offers a variable range of precision (Table 1). Sample 1 (lowmiddle paleogour terrace) is the most undisturbed speleothem (Th-232 contamination is relatively low). Sample 3 (Mazos tufa) is contaminated by Th-232 and the dating age is an 
estimated chronological value. Moreover, sample 4 (La Monjía tufa) is also contaminated, although to a lesser extent than sample 3A, and it was ascribed to a dating age close to the method limit. In addition, sample 8 was collected in a high paleogour terrace and its age is older than the method limit of 350,000 years.

Other areas.

The Ocino spring (Figure 1) is a permanent spring located in the north of the system and it has generated hanging tufas on the slope, although it has not been dated yet. In the Añamaza area, there were three dating samples with age ranges of $75,000 \pm 12,500$ and 225,000 + 25,000/-20,000 B.P., which correspond to isotope stages MIS-1, MIS-5 and MIS-7. Meanwhile, in the Ágreda area, two dating samples from tufas yielded ranges of 180,108 + 9365/ -8754 and 240,034 + 19,920/-16,963 B.P. [30], which correspond to isotope stages MIS-6 and MIS-7. However, in Vozmediano, it seems that there only appeared one isotope stage, 19,159+947/-95 [31], which corresponds to isotope stage MIS-2, during the last glacial cycle.

\subsection{Paleohydrogeology and Natural Recharge in Past Climates: Recharge Variation versus Precipitation and Temperature Using Numerical Simulation}

\subsubsection{Limits in the Use of Mathematical Models for Calculating Past Natural Recharge}

To quantify the hydraulic balance variation of this karstic system by using precipitationrunoff-recharge CREC, there are two main considerations needed for a valid application of this model in past climates. The first is related to contour conditions and the other is soil use. With respect to the former, we can assume that the aquifer's limits and contour conditions are the same or similar to present conditions since at least the Middle Pleistocene. Relief and inward aquifer characteristic modifications are assumed to be insignificant, and, in this period, the last interglacial and the last glaciation stage are included.

The latter is related to land use, which is assumed not to have substantially changed, as will be momentarily explained. According to the multiple factors that interfere in an aquifer's natural recharge [32], in this study zone, and if climatic variables are excepted, it is believed that, from the Neolithic Period to the present, there have not been substantial changes in land use. The most important reason for this is that the stony soil conditions did not allow the development of activities besides bovine and ovine shepherding, which are perfectly adapted to the Sabinar (Spanish juniper forest) open forest assembly (Tertiary remains), where, today, there are vast thymus-prairie surfaces for grazing. According to analysis since the Middle Age, the Sabinar is widespread and covers an important part of the aquifer recharge zone. The forest is constituted by centenary trees, and, in Calatañazor, there are some trees older than 600 years [33]. Moreover, it has been described in historic documents-for example, the Castille Cadaster from the Marqués de la Ensenada (midXVIII century) [34], or the "Noménclator de Despoblados de Soria"-both of which indicate that the area was devoted to grasslands and to Spanish juniper and holm oaks, without the existence of ancient towns, as it is nowadays, where there are solitary territories with majadas (sheepfold) and apriscos (sheep or goat pen) for livestock. During the Medieval epochs, there were no villages in this cold, stony, deprived moor (see Catastro de la Ensenada). Before the Neolithic Period, the aquifer's surface area could have been occupied by spontaneous vegetation, similar to the current flora. Furthermore, investigations of the natural landscape in nearby peat bogs (Hinojosa de la Sierra [35], Calatañazor [36], for example) remark on the predominance of Pinus sylvestris during glaciation and throughout the Holocene, probably in siliceous areas, whereas sabinas, Spanish juniper, grew in calcareous environments. In the last glaciation, this area probably was a steppe or a zone with a few trees, while in the last interglacial period, vegetation was probably less abundant than it is today.

To summarize, in this aquifer, the changes produced by precipitation and temperature from anthropic activity could be well distinguished at least until the Medieval Age. Meanwhile, the results corresponding to the Upper Pleistocene-Holocene should be interpreted with caution, although they could help to provide approximate information about the hydrological reality. 


\subsubsection{Modeling Results}

To simulate the hydraulic behavior of the aquifer over a 21-year (1991-2012) [17] period, a daily flow hydrograph was used to determine the variation in natural recharge and other hydraulic balance variables versus temperature and precipitation fluctuations. Temperature and/or precipitation rises and falls have remained constant every day of the year. Variations could have occurred during the same year, with warmer winters and with colder summers, and with no changes in the average annual temperature, for example, but this did not take place. Moreover, this could have affected the results. Table 2 lists the results of ET (\% respect to 1 year) and natural recharge (R) values with a $1{ }^{\circ} \mathrm{C}$ temperature change in the 1st series, from $-6{ }^{\circ} \mathrm{C}$ to $+6{ }^{\circ} \mathrm{C}$, as well as when precipitation percentage changes from $70 \%$ to $130 \%$ with respect to average precipitation. It lists the number of days of the year when flow from the Fuentetoba spring was over $1000 \mathrm{~L} / \mathrm{s}$ and, consequently, the ephemeral Villaciervos spring and the Son del Agua creek were active.

Figure 6 represents the relationship between natural recharge and evapotranspiration (ET) when the temperature changes within $\pm 6^{\circ} \mathrm{C}$.

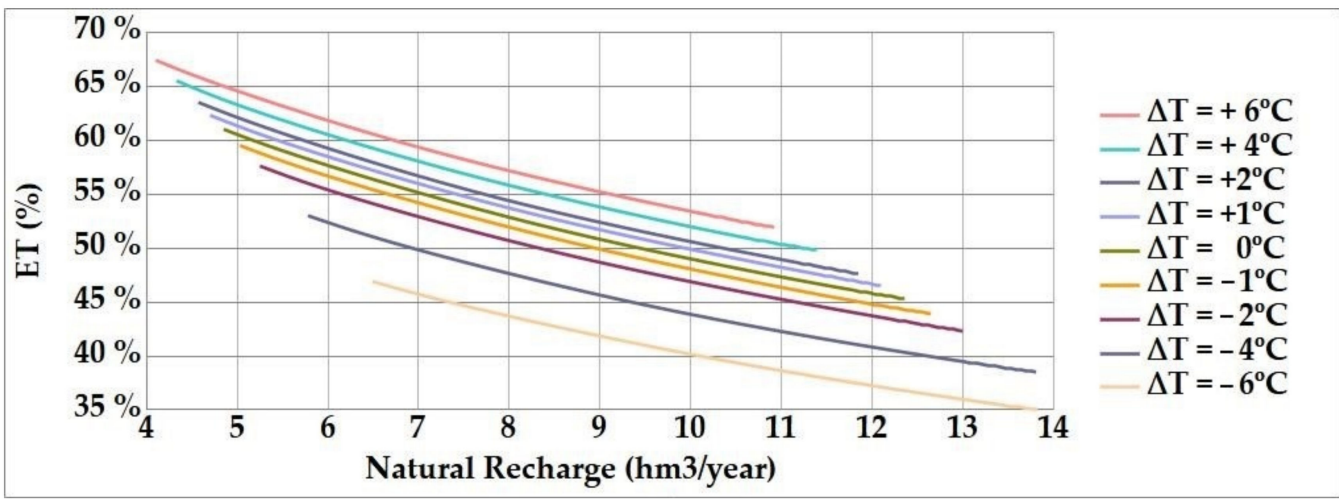

Figure 6. Natural recharge $\left(\mathrm{hm}^{3}\right)$ against evapotranspiration (ET) percentage according to various temperature stages $\pm 6^{\circ} \mathrm{C}$. Data obtained in Fuentetoba spring.

It can be observed that the curved lines are parallel and that the curves with negative increments are separated by a greater distance with respect to the positive increments.

Figure 7 represents the relationship between precipitation, temperature and natural recharge obtained with varying temperatures in the precipitation-runoff model for the simulated series $-4{ }^{\circ} \mathrm{C}, 0^{\circ} \mathrm{C}$ and $+4{ }^{\circ} \mathrm{C}$, and also the precipitation percentage between 100 and $120 \%$ with respect to the mean precipitation.

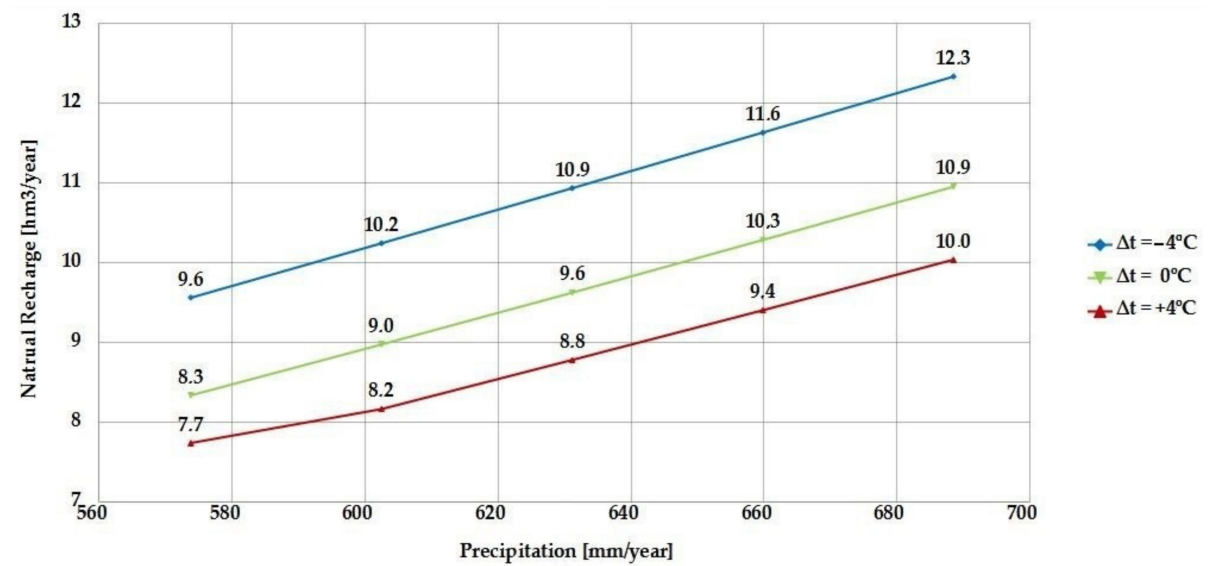

Figure 7. Natural recharge $\left(\mathrm{hm}^{3} /\right.$ year) against precipitation ( $\mathrm{mm} /$ year) according to various temperature stages $\pm 4{ }^{\circ} \mathrm{C}$. Data obtained in Fuentetoba spring. 


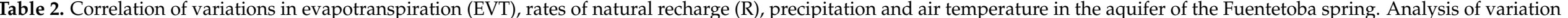

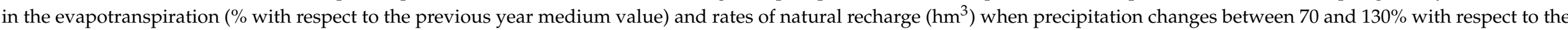

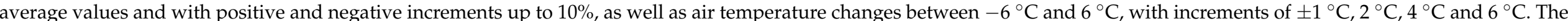
number of days on which the Fuentetoba spring's flow exceeds $1000 \mathrm{~L} / \mathrm{s}$ and is running water on Son del Agua creek from the ephemeral spring in Villaciervos is included.

\begin{tabular}{|c|c|c|c|c|c|c|c|c|c|c|c|c|c|c|c|}
\hline & \multicolumn{3}{|c|}{$P=130 \%$} & \multicolumn{3}{|c|}{$P=120 \%$} & \multicolumn{3}{|c|}{$P=100 \%$} & \multicolumn{3}{|c|}{$P=80 \%$} & \multicolumn{3}{|c|}{$\mathrm{P}=70 \%$} \\
\hline & EVT (\%) & $\mathbf{R}\left(\mathrm{hm}^{3}\right)$ & días > $1.000 \mathrm{1} / \mathrm{s}$ & EVT (\%) & $\mathbf{R}\left(\mathrm{hm}^{3}\right)$ & días $>1.0001 / \mathrm{s}$ & EVT (\%) & $\mathbf{R}\left(\mathrm{hm}^{3}\right)$ & días $>1.0001 / \mathrm{s}$ & EVT (\%) & $\mathbf{R}\left(\mathrm{hm}^{3}\right)$ & días > $1.0001 / \mathrm{s}$ & EVT (\%) & $\mathbf{R}\left(\mathrm{hm}^{3}\right)$ & días $>1.000 \mathrm{l} / \mathrm{s}$ \\
\hline$\Delta \mathrm{T}=-6^{\circ}$ & $34.0 \%$ & 14.77 & 35.0 & $35.6 \%$ & 13.31 & 32.0 & $39.4 \%$ & 10.48 & 24.5 & $44.1 \%$ & 7.78 & 17.4 & $46.9 \%$ & 6.49 & 13.8 \\
\hline$\Delta \mathrm{T}=-4^{\circ}$ & $38.5 \%$ & 13.81 & 32.5 & $40.3 \%$ & 12.38 & 29.4 & $44.5 \%$ & 9.62 & 22.8 & $49.8 \%$ & 7.01 & 14.6 & $53.0 \%$ & 5.78 & 10.1 \\
\hline$\Delta \mathrm{T}=-2^{\circ}$ & $42.3 \%$ & 13.00 & 31.3 & $44.3 \%$ & 11.61 & 28 & $48.8 \%$ & 8.93 & 20.6 & $54.3 \%$ & 6.42 & 12.4 & $57.6 \%$ & 5.25 & 8.5 \\
\hline$\Delta \mathrm{T}=-1^{\circ}$ & $43.9 \%$ & 12.65 & 30.1 & $45.9 \%$ & 11.28 & 27.5 & $50.6 \%$ & 8.64 & 19.3 & $56.2 \%$ & 6.18 & 12 & $59.5 \%$ & 5.03 & 8 \\
\hline$\Delta \mathrm{T}=0^{\circ}$ & $45.3 \%$ & 12.36 & 29.3 & $47.3 \%$ & 11.01 & 26.7 & $52.0 \%$ & 8.4 & 18.5 & $57.7 \%$ & 5.98 & 11.3 & $61.0 \%$ & 4.85 & 7 \\
\hline$\Delta \mathrm{T}=+1^{\circ}$ & $46.5 \%$ & 12.10 & 29 & $48.6 \%$ & 10.76 & 25.8 & $53.3 \%$ & 8.19 & 18.2 & $59.0 \%$ & 5.8 & 11 & $62.3 \%$ & 4.7 & 7.4 \\
\hline$\Delta \mathrm{T}=+2^{\circ}$ & $47.6 \%$ & 11.85 & 29.2 & $49.7 \%$ & 10.53 & 25.9 & $54.4 \%$ & 7.99 & 17.8 & $60.2 \%$ & 5.65 & 10.5 & $63.5 \%$ & 4.57 & 6.8 \\
\hline$\Delta \mathrm{T}=+4^{\circ}$ & $49.8 \%$ & 11.39 & 28.3 & $51.8 \%$ & 10.1 & 25.1 & $56.6 \%$ & 7.63 & 17 & $62.2 \%$ & 5.37 & 10.1 & $65.5 \%$ & 4.33 & 7.9 \\
\hline$\Delta \mathrm{T}=+6^{\circ}$ & $51.9 \%$ & 10.92 & 27.2 & $54.0 \%$ & 9.66 & 23.5 & $58.7 \%$ & 7.28 & 16.2 & $64.3 \%$ & 5.09 & 9.6 & $67.4 \%$ & 4.1 & 6.0 \\
\hline
\end{tabular}


Firstly, it can be observed that this is a linear relationship, because, even when mean annual values are selected, recharge can vary abundantly between seasons. In arid and semiarid regions, it was observed that, during prolonged dry periods, the recharge is lower than the average, while in wet periods, it is higher than the average.

In the figure, we can see that recharge variation is different when the temperature rises or falls since the straight lines are separated differently: the absolute values of recharge double when the temperature drops by $1^{\circ} \mathrm{C}$ (the temperature rises by $1^{\circ} \mathrm{C}$ ). In the Fuentetoba spring, if the temperature declines by $-1{ }^{\circ} \mathrm{C}$, the flow increases to $7.6 \mathrm{~L} / \mathrm{s}$ (flow average is $264 \mathrm{~L} / \mathrm{s}$ ) approximately. The flow lowers to $6.8 \mathrm{~L} / \mathrm{s}$ if the temperature increases by $1^{\circ} \mathrm{C}$, for example. At $-4{ }^{\circ} \mathrm{C}$, the flow rises to $38.8 \mathrm{~L} / \mathrm{s}$, and at $+4{ }^{\circ} \mathrm{C}$, the flow drops to $18.9 \mathrm{~L} / \mathrm{s}$, whereas precipitation has a greater impact than temperature; that is, if the precipitation rises to $120 \%$, the flow in the spring rises to $346.9 \mathrm{~L} / \mathrm{s}$.

Figure 8 plots the variation in the natural recharge respect EV (EVT) for an increase or decrease in constant mean annual precipitation. It can be observed that the lines are not parallel and that they converge when $\mathrm{EV}=100 \%$ and the natural recharge is null $\left(\mathrm{NR}=0 \mathrm{hm}^{3}\right)$.

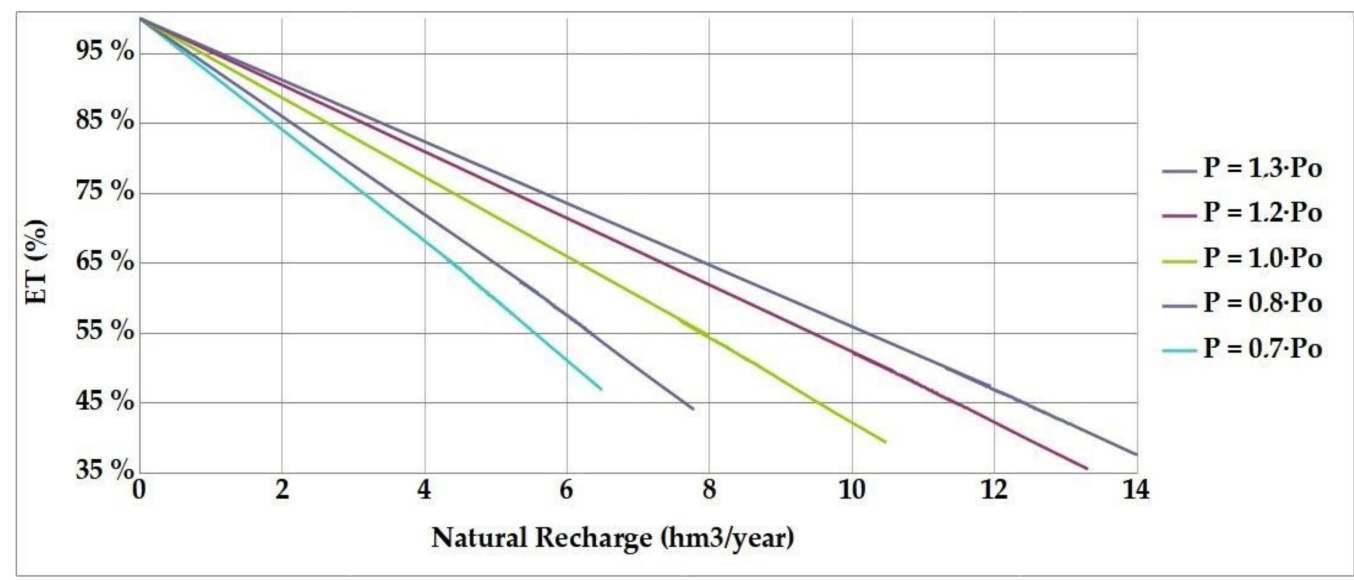

Figure 8. Natural recharge $\left(\mathrm{hm}^{3}\right)$ against evapotranspiration (ET) percentage according to various precipitation stages, with $\mathrm{P}_{\mathrm{o}}$ being annual precipitation. Data obtained in Fuentetoba spring.

\section{Discussion: Paleohydrological Evolution of the Karstic System during the Late Miocene and Quaternary}

\subsection{The Earliest Stages of Karstification in the Aquifer}

The characteristics of the upper galleries of the Majada del Cura cave reveal its hydrogeological history: after the constitution of the Astaracian erosion surface [22] and the late Turonian beginning of its regional exhumation process (9-5.3 Ma) [22], a slow flow modeled a paragenetic gallery densely filled with clay. These galleries have an accumulation site near the emergence zone, which is the cave entrance, with a cylindrical conduit. Furthermore, there are other indications of the pre-Quaternary phreatic conditions, such as scallops on the walls. They reveal an ancient permanent phreatic regime with slow flow in submerged galleries, where continued sedimentation of fine materials on the floor and the cupola was observed, eroded by corrosion on the passage ceiling. The phreatic level then was extremely close to the topographic surface.

The external erosion had not yet developed steep topographic slopes, so the springs were still situated on high moorland, and the hydraulic gradients of the groundwater flow were consequently small. Moreover, there was incipient karstification that was constrained to the more active hydrodynamic upper part of the aquifer. Despite not being the predominant source of underground drainage, this could be explained by its coexistence with a relatively important runoff, which is represented by a relict entrenched network. The same condition occurs on the calcareous moor, located to the south of the study area, where the karst system's edges are yet not eroded and the relief has evolved slightly. Here, 
the drainage network is constituted by dry valleys of recharge and only one perennial spring of $10 \mathrm{~L} / \mathrm{s}$ flow (Villabuena spring). During rainy periods, water flows through some of these valleys, and the above-mentioned spring's flow increases strongly (up to $500 \mathrm{~L} / \mathrm{s}$ ) as a consequence.

With the passing of time and the lowering of the base level by external erosion, the water flow will disappear in these paragenetic passages due to the lowering of the water table. Moreover, these galleries remain hanging above new, syngenetic, active, re-excavated galleries. The two principal hypogean flow passages have been stacked alongside a specific limestone layer attached to the Fuentetoba anticline acute crest. Furthermore, the layers follow an east-west direction and dip between 45 and 65 degrees in the northern flank. Therefore, the strata strike has conditioned the linear karst network. Moreover, the limestone banks are the same as those where Fuentetoba spring emerges. Consequently, it is quite probable that the explored gallery network persists in a straight line towards the east until it reaches the emergence, which is the final destination of the hypogean river.

Over the eroded surfaces, some exokarst forms have been previously developed; dolines, uvalas and karren fields. The Plio-Quaternary stage has been considered by some authors as the main karstification stage in the whole Mediterranean area [37,38]. However, in this zone, according to the age of the paleontological karstic fill deposit in Escobosa de Calatañazor, the late Middle Miocene might be applicable [39].

\subsection{Paleohydrologic Evolution Proposed Since the Late Miocene and during the Quaternary}

After the initial stages in the karstic system formation, a hypogean network was developed as the result of the karstification process in the vadose zone during an extensive period (late Miocene and Quaternary), perhaps 5 million years. However, this study only involves the last 0.3 M.y., due to the age of the tufas associated with the Fuentetoba spring and La Monjía as well as the age of the cave paleogours. During this time, flow was focused and directed towards the southern syncline flank's lower zone from the permeableimpervious (limestone-Cenomanian marl, respectively) contact. Nowadays, the La Toba spring is the deepest area of this contact and has also been the main drainage point over a large part of the Quaternary, although it has been slightly lowered following the Golmayo River's erosion path and has been somewhat shifted towards the north, in accordance with the above-mentioned dip contact. This is the only place where the tufa deposit appears, and it does not exist in the whole northern flank or in the rest of the periclinal closure, where the contact is always situated at higher altitudes. Therefore, an earlier timepoint should have been attributed to this emergence, explaining the enormous volume of tufa associated with the emergence. Moreover, the tufa remains in La Monjía (slightly above the La Toba tufa and $250 \mathrm{~m}$ eastwards) could be related to the main discharge zone. Within the discharge zone, there are remains of an ancient adjacent spring that was gradually abandoned, because there are tufa structures along almost the entirety of the permeableimpervious contact, but the emission point moved backwards to another position to where the La Toba spring is today. However, this abandonment is not definitive since, in high waters, a small spring may emerge.

The stability is the result of the resistance of Pico Frentes and the Sierra de La Llana to erosion during the Late Miocene and Quaternary. The adjacent territory, since the Turonian Period, has been emptied out by erosion [22], as mentioned before, but mainly from the ante-fluvial pediment at an altitude of $1070 \mathrm{~m}$, and this is where the Douro River and its tributaries are entrenched.

If, in a cross-section, we represent (Figures 9 and 10) the Astaracian Erosion Surface (1200-1250 m), the anti-fluvial pediplain (1070 m), the upper terrace (1077-1087 m), middle terrace (1037-1042 m) and the lower terrace of the Douro River (1020-1026), situating the Douro River at an altitude between 1017 and $1023 \mathrm{~m}$, we can see that the lowering of the fluvial base level from the initial IES amounts to more than $200 \mathrm{~m}$. Moreover, the denudation is greater than the lowering of the hypogean river's base level, which was conditioned by the lowering of the point of emergence at La Toba. However, it has not 
occurred parallel to the fluvial entrenchment, because the latter has remained hanging on the slope at $55 \mathrm{~m}$ above Fuentetoba village, for example.

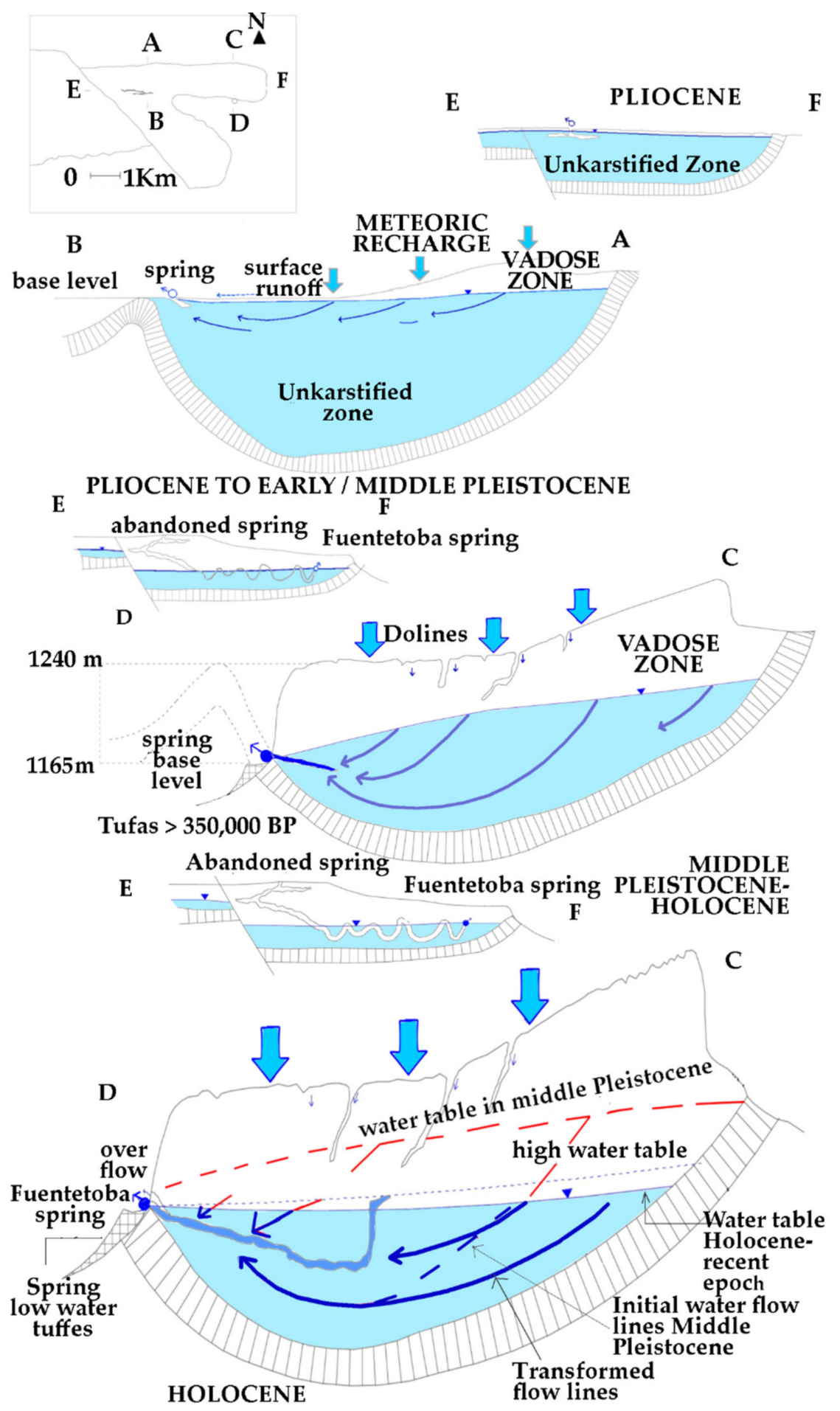

Figure 9. Evolution of Fuentetoba karst system with the karstic base level due to the external erosion of the relief. The system has evolved from a Miocene peneplain aquifer (above) up to a highly karstified syncline basin from almost the Middle Pleistocene to the present. The concentration of flow lines for a long time in the Fuentetoba spring led to the development and enlargement backwards of a large drainage conduit. Shown in this Figure 9 cross sections EF, BA and DC in different ages: Pliocene, Early Pleistocene, Middle Pleistocene, and Holocene. 


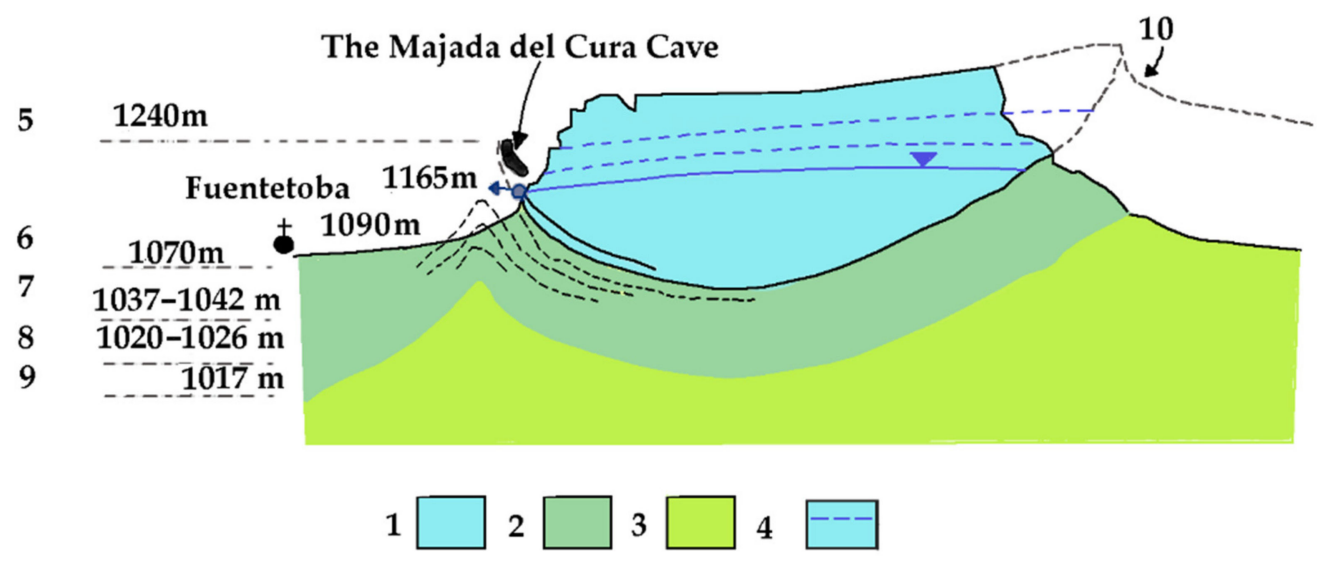

Figure 10. Relief evolution scheme and its relationship with the cavity's formation and Fuentetoba spring. 1. Aquifer, limestones, 2. Marls, 3. Utrillas facies sandstones, 4. Waterlines, ancient phreatic levels.

This hydrostratigraphic contact has decreased during the Miocene and Quaternary Periods. The emergence has also decreased, albeit more slowly (Figure 9). For this reason, a time-lapse of hundreds of thousand years since the Turonian Period has separated the generation processes of this cave. Although the river's entrenchment did not accompany the hypogean river, and the emergence at La Toba remained fixed, the whole entrenchment process occurred at a different pace. Consequently, it is impossible to correlate the galleries' levels to either erosion surfaces or Douro River terrace levels.

The lowering amounts to more than $75 \mathrm{~m}$ from the altitude of the Majada del Cura cave entrance $(1240 \mathrm{~m})$. Although we do not have chronological data about the age of the upper gallery formation, it is assumed that it would be similar to the age of La Galiana's upper cave (3.5 My.) [40], It would be a $21 \mathrm{~mm} / \mathrm{ka}$ entrenchment, which is less than half of the Lobos River's maximum fluvial entrenchment (between 39 and $58 \mathrm{~mm} / \mathrm{ka}$ ) [40].

These relatively stable topographic and geological conditions created flow lines that converged to the emission point. Therefore, the flow and velocity were enlarged in the vicinity, where the dissolution was at its maximum. The emergence point was shifted downwards, the water table was lowered, and the thickness of the saturated zone was also reduced, while the porosity increased. Most of the flow, as nowadays, came from the west side of the syncline, where the center of gravity of the recharge area is situated.

The hypogean river entrenchment between paleogour terraces $(188,000 \mathrm{BP}$ dated) and the actual riverbed does not exceed $4 \mathrm{~m}$. In the past, each slope break and waterfall jump conditioned the formation of rimstone gours, giving rise to a lacustrine phase more important than the current one. With the succession of lakes, and where the river flow was precarious, water agitation buoyed calcium carbonate precipitation, i.e., the actual river profile is similar to the ancient one. The stalagmitic crusts usually testify to an ancient incrusting flow during the phase of flow decrease, which corresponds to a drier period and/or the river being derelict when the river flow was more precarious. These crusts reflect an ancient incrusting flow, which corresponds to 188,000 BP in the lower terrace and more than 350,000 BP in the upper terrace, i.e., in the Middle-Upper Pleistocene. Moreover, the crust is eroded by potholes, which were formed during an ancient turbulent flow with whirlpools. Inside the potholes, there are still rounded limestone pebbles.

The river entrenchment should correspond to cold stages during the last glacial period and later. Not all gours are eroded, and some barrier gours are semi-functional in their upper parts but they display potholes in the lower part.

Some of the tufas from La Monjía are found at the limit of the optimum conditions of the U-Th method; nevertheless, it seems certain that this spring has been operating for more than 350,000 years, and the Fuentetoba spring since at least 250,000 B.P., during the Middle Pleistocene. It was observed that the emergence point has relocated $250 \mathrm{~m}$ to the west. The Mazo River spring is modern and was active 39,000 years ago (B.P.), in the Upper 
Pleistocene, which corresponds to the base of the tufa formations. As a result, during the Middle-Upper Pleistocene-Holocene (and possibly before), the Fuentetoba spring was a steady drainage point. Towards this point, most of the flows of the three synclines have been directed from this system's aquifer, using the Ocenilla Fault as a water conduit. Since 39,000 B.P., a lesser part, the syncline flow from the Alto de la Cruz, has been redirected by the same fault southwards (opposite direction) to overflow in the Mazos River spring. In theory, this spring should have been the principal point of natural emergence of the two synclines due to their proximity. Moreover, this highlights that the flow was redirected over most of that time to a distant spring (Fuentetoba) on the aquifer's eastern edge.

An explanation of this apparent hydrogeological abnormality is that the network of inner passages was inherited from a previous topographic-geological situation that is different from the current one. Moreover, after persisting for a long period of time, it established a conduit network, which is being used by the actual groundwater seepage. Nevertheless, as the system's external periphery had been affected by erosion, and the frost weathering caused a shrinking of the limestone cliff during the Middle Pleistocene, the topographic conditions established a hydraulic gradient in the Ocenilla Fault, yet, due to its strength, it could drive a part of the flow toward the Mazos River spring. Furthermore, this also explains the colossal dimensions of the Fuentetoba spring's emergence conduit, since, for a long time, it drained off an excess of $50 \mathrm{~L} / \mathrm{s}$, which is now considered to be the medium flow of the Mazos River.

On the other hand, the larger conduit associated with the Fuentetoba spring can be interpreted as the product of the widening and backward growth of the spring, most likely due to the dissolution from the concentration of paleo-flows during part of the Quaternary (Figure 9). In addition to the vast development and size of the conduit, it would seem that dissolution in this natural tube has been present for hundreds of million years. Moreover, the tube is still active because groundwater flow is significant, though it does not seem to be the main emergence conduit nowadays. This pipe could indicate that, in the past, it had been a more influential collector as well as more functional than in present times, before the necessity of safely evacuating large discharge flows, as mentioned before. Epochs that corresponded with more humid climates and with more recharge resulted in a more active aquifer hydrodynamic.

To summarize, the development acquired by this still-active conduit apparently does not appear to correspond to the low-flow spring that it is nowadays $(200 \mathrm{~L} / \mathrm{s}$ mean; overflow $3000 \mathrm{~L} / \mathrm{s}$ and during low water periods few L/s). This passage's cross-section should have grown over time by corrosion processes until it reached an equilibrium with the drainage capacity that the aquifer demanded. On the other hand, the conduit was deprived of fill, indicating an active groundwater circulation with velocity, which delays both sand and clay sedimentation, enhancing the corrosion. According to the scallop length and the hydraulic diameter, according to [41], a mean paleo-flow velocity of 10-15 cm/s can be calculated, which is above the mean critical velocity in a laminar flow for a cylindrical conduit that has a diameter of $1.5 \mathrm{~m}$ and a $15^{\circ}$ dip, i.e., this conduit's paleoregimen was turbulent, and its velocity was approximately equivalent to a flow between 800 and $900 \mathrm{~L} / \mathrm{s}$.

The rise in sea level by the rapid water table elevation due to the recharges produced by the intense precipitation or melting increases the difference in hydraulic potential between the inferior and superior edges of the pipe, increasing its flow and velocity. To summarize, this system presents high flow and pressure variations, passing quickly from laminar to turbulent flow.

In fact, this aquifer displays an inherited, properly developed and completed karstification system, which makes it an efficient drainage system.

Effectively, on one side, there is a sloping gallery of notable length, which penetrates into the aquifer's saturated zone, and a gallery in free flow in a perpendicular direction in the lowest outer part that recollects the runoff from the aquifer's circulation in the free regimen. These natural capturing systems succeeded in lowering the phreatic level and impeding sudden increases in the spring as a result of precipitation. 


\subsection{What the Tufas Reveal about the Paleoclimatology of the Middle-Upper Pleistocene}

From a paleoclimatic point of view, the formation periods of tufas are generally related to the early and humid phases during the Middle-Upper Pleistocene and Holocene; thus, they are ultimately linked to the water availability during interglacial periods (odd isotopic stages of [29]).

In this karstic system, it is significant that tufas from the Fuentetoba springs (probably MIS-11 in La Monjía tufas, MIS-9 and limit between MIS-7 and MIS-8), in the Pachón cave (MIS-3) and the paleogours in the Majada del Cura cave (possibly MIS-11 in the upper paleogours and limit MIS- 6 to MIS-7 in the low terrace) may correspond to the template or interglacial periods. Moreover, not only do they coincide with some of the stages in Añamaza tufas (MIS-7, MIS-5 and MIS-1) that we or [18] have dated, but also with Agreda's (MIS-7, MIS-6 and MIS-3) [31].

Furthermore, in this area, tufas are associated with interglacial periods, although this is not always the case, as with the examples of Vozmediano (MIS-2) and Ágreda (MIS-6), which signal that the tufa generation had not been interrupted at all. The stages with the largest instance of tufaceous recorded, with adequate temperatures and water supply for their development, are nearby in Añamaza and Ágreda [31] as well as the rest of the Aragon Iberian Range, corresponding to the stages MIS-9, MIS-7, MIS-5 and MIS-1 [15]. The stages MIS- 5 and MIS- 1 are considered to be some of the most propitious in the Iberian Peninsula for the tuffaceous sedimentation, associated with humid periods [14]. The stage MIS-3 would correspond to Mazos River tufas, close to the Wurm II/III inter-stage, with a warm and very wet climate.

It is probable, however, that this stage was not as prone to tufa generation [42]; it was identified in the Ágreda area (Figure 5). La Monjía may correspond to the MIS-11 stage, such as in the paleogours of the high terrace, but this is yet to be confirmed.

\subsection{Natural Recharge Variations in Earlier Climatic Stages}

As mentioned previously, Figure 7 represents the relationship between pluviometry, temperature and natural recharge that was obtained with the change in temperature and the pluviometry percentage. It is primarily observed through a linear relationship, as the average annual values were selected, although the recharge has larger seasonal variations. We also observe that the recharge does not change equally if the temperature increases or decreases since the distance between curves is different: recharge increases, in absolute values, by two times when the temperature drops by $1{ }^{\circ} \mathrm{C}$, leading to an increase of 1 degree Celsius. When the temperature decreases by $1^{\circ} \mathrm{C}$, the Fuentetoba flow (average $264 \mathrm{~L} / \mathrm{s}$ ) rises by $7.6 \mathrm{~L} / \mathrm{s}$, and it falls by $6.8 \mathrm{~L} / \mathrm{s}$ if the temperature rises by $+1{ }^{\circ} \mathrm{C}$, for example. Furthermore, pluviometry has a stronger influence than temperature: even if the temperature remains constant but pluviometry increases to $120 \%$, the spring's flow rises to $346.9 \mathrm{~L} / \mathrm{s}$.

If we consider, for example, the climatic stages during the Holocene in Northeastern Spain (see, as an example, [40]), where the temperature appears to have been oscillating between $+2{ }^{\circ} \mathrm{C}$ (Atlantic Climatic Optimum) and $-2{ }^{\circ} \mathrm{C}$ (The Younger Dryas), we can infer from these data that, if precipitation remains constant, the Fuentetoba spring's mean annual flow would fluctuate between $283 \mathrm{~L} / \mathrm{s}$ and $253 \mathrm{~L} / \mathrm{s}$. During the Little Ice Age, when temperatures may have fallen by nearly $1{ }^{\circ} \mathrm{C}$ in the nearby Pyrenees Mountains [43], the mean flow in Fuentetoba may have been $272 \mathrm{~L} / \mathrm{s}$. Large flows would also increase slightly above $1000 \mathrm{~L} / \mathrm{s}$, as shown in the Flow Duration Curve (FDC) (Figure 11), although the number of days above this flow was almost the same (Table 2).

If, during the last glaciation, we suppose that the average temperature rose by $6^{\circ} \mathrm{C}$ and the temperature rose by $20 \%$, the flow from the Fuentetoba spring would have risen substantially until $422 \mathrm{~L} / \mathrm{s}$. However, mainly, the discharge stages would increase due to snowmelt and maximum flow, with peaks over $14,000 \mathrm{~L} / \mathrm{s}$, indicating the importance of snow recharge. On the other hand, the cold-water level rises in the spring during glacial periods would constrain tufa formation or be destructive. The Villaciervos trop- 
plein would increase its life from 18 to 32 days. However, this could explain why there is a sculptured valley by a creek that often flowed with water, yet we now only see it in exceptional circumstances. Moreover, the absence of tuffaceous deposits in this resurgence explains that its activity was associated with cold periods, as well as with its flow faults.

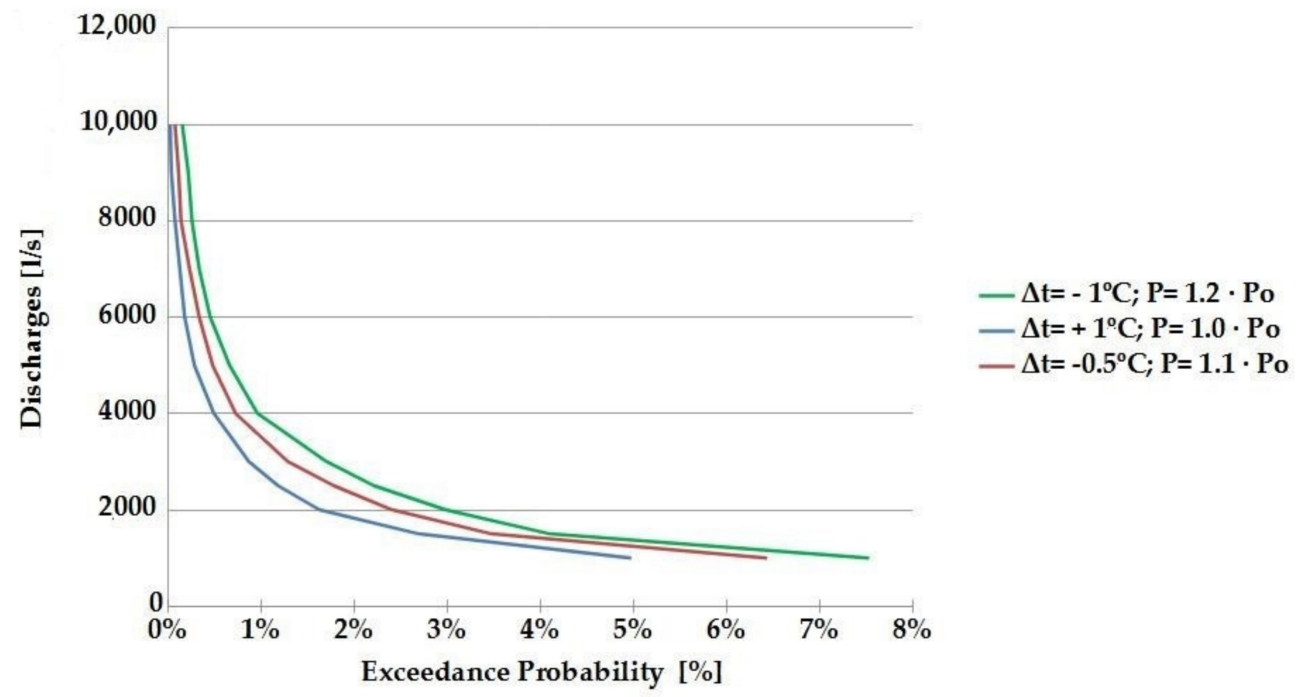

Figure 11. Flow duration curves for different precipitation-runoff situations and temperatures. Data obtained in Fuentetoba spring.

\section{Conclusions}

As is shown in this work, most karst systems are much more complex than they appear. The development of subterranean karst systems is closely dependent on climatic cycles, groundwater and the evolution of the relief. Consequently, karst aquifers are a benchmark for global climate change and other anthropogenic environmental challenges. In this sense, an interdisciplinary study is carried out that attempts to advance karst science with the aim of conservation and sustainable management of this karst system.

Hydric resource exploitation in the karst must be sustainable, and it is important to advance the existing recharge assessment methods and knowledge of climate change impacts on hydric resources [44]. It is also important to better preserve drinking water recharge areas and the associated geological heritage so that the modeling and characterization of karstic aquifers can be carried out. Moreover, a karst is a heterogeneous environment that changes from one point to another, so a good knowledge of the local characteristics is very important. Consequently, for the appropriate management and conservation of the karstic environment, it is necessary to perform resource assessment as well as the characterization of the hydrogeological function of the aquifer. The latter will depend much more on previous hydrogeological history [45]. In this sense, and based on previous knowledge of the site $[1,17,20,21,33,46,47]$, interdisciplinary work was carried out that included conventional speleology, spelodiving, endokarst study, previously determined conventional hydrogeology, as well as modeling, external geomorphology and the study and dating of speleothems.

These contribute to the improvement of the knowledge of a peculiar karstic system genesis as well as its evolution through recent geological times.

The observations made in the main cave of the karst system indicate that a period of some million years distances us from the cave's generative processes, which combined the syngenetic (lower part) and paragenetic galleries (upper part) within the same underground network.

Both networks are superimposed along the same geological contact, indicating the existence of only one sort of hydrogeological organization, which has evolved over the course of several million years in the Neogene and the Quaternary. 
The cave is the result of the excavation process of the same water flow, which has been entrenched, abandoning the vadose free flow and switching from phreatic to vadose conditions. The entrenchment was conditioned by the karstic base level. Furthermore, it was lower than at the epikarst rivers. As a result, huge hanging paleogours were formed in the initial phreatic passage, within the upper network, with its emergence on the higher plain before the relief flattening. Moreover, an active hypogean river may be the leading pipe in the karstic system of the Fuentetoba spring nowadays. Flow lines converged at Fuentetoba spring, and, by dissolution, a drainage cylindrical conduit in the saturated zone in the synclinal basin was developed.

The inherited conduit network has conditioned the current hydrogeological behavior by inertia. Favored by the situation and the calcareous tufa dating, it was possible to determine that even though the flow within the aquifer was mainly directed towards this spring for a long time, during the late Upper Pleistocene, a substantial component of the groundwater flow was driven towards the spring of the Mazos River source. This dating of tufas and speleothems provides information about the aquifer's different phases during the recent Quaternary and, as a result, about the different feeding and recharge processes. These tufas and paleogours correlate with each other and are also associated with the warm periods of the most recent Quaternary, according to the regional context when the natural recharge was lower.

The karst system also gathers conditions as a pilot aquifer by approximately quantifying the natural recharge variation in these different climatic stages. Through a precipitationrunoff-recharge model, it was possible to prove that, as the recharge increased by $160 \%$ during the last glaciation, the peaks in the hydrograph also rose in a spring influenced by the snowy climate and functioned as a far off trop-plein. This model may be used as a forecast of the recharge's future evolution against precipitation and temperature change scenarios.

Author Contributions: Conceptualization, E.S.P.; methodology, C.F. and E.S.P.; software, P.R.R.; validation, E.S.P., C.F. and P.R.R.; formal analysis, E.S.P. and C.F.; investigation, C.F., E.S.P. and P.R.R.; resources, I.M.P.; data curation, P.R.R. and E.S.P.; writing—original draft preparation, C.F. and E.S.P.; writing - review and editing, I.M.P.; visualization, C.F., E.S.P., P.R.R. and I.M.P.; supervision, E.S.P. and I.M.P.; project administration, E.S.P. and I.M.P.; funding acquisition, E.S.P. All authors have read and agreed to the published version of the manuscript.

Funding: This research received no external funding.

Institutional Review Board Statement: Not applicable.

Informed Consent Statement: Not applicable.

Data Availability Statement: Not applicable.

Acknowledgments: Authors are grateful to Carlos Morón and the speleology groups Club de Deportes Espeleo, Club Deportivo Terrasub and Sociedad Espeleológica Alto Duero for supporting the field research and cave network topography and exploration.

Conflicts of Interest: The authors declare no conflict of interest.

\section{References}

1. Sanz, E.; Rosas, P.; Menéndez-Pidal, I.; De Ojeda, J.S. Modeling and Prefeasibility Management, and Conservation Strategies for Fuentetoba Springs, (Spain). Sustainability 2020, 12, 131. [CrossRef]

2. Ford, D.C.; Williams, P.W. Karst Geomorphology and Hydrology; Unwin Hyman: London, UK, 1989; p. 601.

3. Ford, D.C.; Williams, P.W. Karst Hydrogeology and Geomorphology; Wiley: Chichester, UK, 2007.

4. Bakalowicz, M. Karst groundwater: A challenge for new resources. Hydrogeol. J. 2005, 13, 148-160. [CrossRef]

5. Hernanz, A. Aspectos Generales de la Hidrología del Karst. Curso de Hidrología General y Aplicada. Escuela de Hi-drología; Centro de Estudios Hidrográficos: Madrid, Spain, 1979; p. 29.

6. Renault, P. Contribution a l'etude des actions mecaniques et sedimentologiques dans la speleogenese. Ann. Speleol. 1967, 22, 259-307. 
7. Renault, P. La Formation des Cavernes. Presses Universitaires de France, Collection Que-sais-je, 1400, Paris, 1970; 126p. Available online: https://journals.openedition.org/geomorphologie/9547 (accessed on 23 June 2021).

8. Klimchouk, A.B.; Ford, D.C.; Palmer, A.N.; Dreybrodt, W. (Eds.) Speleogenesis: Evolution of Karst Aquifers: Hunts-Ville, Ala; National Speleological Society Huntsville: Huntsville, AL, USA, 2000; p. 527.

9. Rhoades, R.; Sinacori, M.N. Pattern of Ground-Water Flow and Solution. J. Geol. 1941, 49, 785-794. [CrossRef]

10. Bakalowicz, M. Géochimie des eaux karstiques et karstification. (Karst groundwater geochemistry and karstification). Ann. Spéléologie 1975, 30, 581-589.

11. Atkinson, T.C. Diffuse flow and conduit flow in limestone terrain in the Mendip-Hills, Somerset (Great Bretain). J. Hydrol. 1977, 35, 93-110. [CrossRef]

12. Dreybrodt, W. Limestone Dissolution Rates in Karst Environments; Bulletin d'Hydrogéologie; Centre d'Hydrogéologie, Université de Neuchâtel: Neuchatel, Switzerland, 1998; Volume 16, pp. 167-183.

13. Andrews, J.E. Paleoclimatic records from stable isotopes in reverine tufas: Synthesis and review. Earth Sci. Rev. 2006, 75, 85-104. [CrossRef]

14. Gonzalez Martin, J.A.; Gonzalez Amuchastegui, M.J. (Eds.) Las Acumulaciones Tobaceas. Sociedad Española de Geomorfologia. Las Tobas en España. SEG, Badajoz. 2014, pp. 3-18. Available online: https://geomorfologia.es/publicaciones/libros (accessed on 23 June 2021).

15. Peña, J.L.; Sancho, C.; Arenas, C.; Auque, L.; Longares, L.A.; Lozano, M.V.; Melendez, A.; Osacar, C.; Pardo, G.; Vazquez Urbez, M. Las Tobas Cuaternarias en el Sector Aragonés de la Cordillera Iberica. Sociedad Española de Geomorfologia. Las Tobas en España. SEG, Badajoz. González Martín, J.A., González Amuchastegui, M.J., Eds.; 2014, pp. 159-172. Available online: https:/ / geomorfologia.es / publicaciones / libros (accessed on 23 June 2021).

16. Swanson, S.K.; Muldoon, M.; Polyak, V.; Asmerom, Y. Evaluating shallow flow-system response to climate change through analysis of spring deposits in southwsetern Wisconsin, USA. Hydrogeol. J. 2014, 22, 851-863. [CrossRef]

17. Sanz, E.; Rosas, P.; Menéndez-Pidal, I. Hidrogeología del Karst de Pico Frentes (Cordillera Ibérica, España). Estud. Geológicos 2016, 72, e047. [CrossRef]

18. Arenas, C.; Sancho, C.; Vazquez-Urbel, M.; Pardo, G.; Hellstrom, J.; Ortiz, J.E.; Torres, T.; Cinta Osácar, M.; Auqué, L. Las tobas cuaternarias del río Añamaza (provincia de Soria, Cordillera Ibérica): Aproximación cronológica. Geogaceta 2010, 49, 51-54.

19. Hellstrom, J. Atomic Spectrometry. J. Analytical. 2003, 18, 1346-1351.

20. Sanz, E.; Rosas, P.; Menendez-Pidal, I. Drainage and siphoning of a karstic spring: A case study. J. Cave Karst Stud. 2016, 78, 183-197. [CrossRef]

21. Fonolla, C.; Sanz, E.; Menendez-Pidal, I. Lateral ferruginous groundwater transfer as the origin of the iron crusts in caves: A case study. J. Cave Karst Stud. 2020, 82, 183-197. [CrossRef]

22. Benito-Calvo, A.; Pérez-González, A. Erosion surfaces and Neogene landscape evolution in the NE Duero Basin (north-central Spain). Geomorphology 2007, 88, 226-241. [CrossRef]

23. Rodríguez-García, J.A. Geomorfología de un Sector de la Cuenca de Almazán (Soria): Procesos de Erosión de Suelos y Planteamiento de Escenarios Ante el Cambio Climático. Ph.D. Thesis, Univ. Complutense de Madrid, Madrid, Spain, 2008 ; p. 390.

24. IGME (Instituto Geológico y Minero de España). Mapa Geológico de España 1: 200.000. Hoja 31. Soria. Ed. IGME, Madrid, España. 1980. Available online: http:/ /info.igme.es/cartografiadigital/portada/default.aspx?mensaje=true (accessed on 23 June 2021).

25. Sanz, E. El Relieve de la Sierra de Cabrejas. III Congreso Geológico de España y I Congreso Iberoamericano de Geología. Salamanca, Spain Tomo 3. 1992, pp. 91-95. Available online: https://soporte.dialnet.unirioja.es/portal/es/kb/articles/acceso-adocumentos-a-texto-completo (accessed on 23 June 2021).

26. IGME (Instituto Geológico y Minero de España). Mapa Geológico de España 1: 50.000. Hoja 349. Cabrejas del Pinar.. Ed. IGME, Madrid, España. 1982. Available online: http://info.igme.es/cartografiadigital/portada/default.aspx?mensaje=true (accessed on 23 June 2021).

27. Pérez, J.; Sanz, E. Hydrodinamic characteristics and sustainable use of karst aquifer of high environmental value in the Cabrejas range (Soria, Spain). Environ. Earth Sci. 2010, 1, 20-30. [CrossRef]

28. Sanz Perez, E. Las Aguas Subterraneas en Soria. Ediciones Diputación Provincial de Soria. Coleccion Temas Sorianos $n^{\circ} 39$ Soria, España. 1999. Available online: https:/ / scholar.google.es/scholar?hl=es\&as_sdt=0\%2C5\&q=+Sanz+Perez\%2C+E.1999.+Las+ aguas+subterraneas+en+Soria.Ediciones+Diputaci\%C3\%B3n+Provincial+de+Soria.\&btnG= (accessed on 23 June 2021).

29. Shackleton, N.J.; Opdyke, N.D. Oxygen isotope and palaeomagnetic stratigraphy of Equatorial Pacific core V28-238: Oxygen isotope temperatures and ice volumes on a 105 year and 106 year scale. Quat. Res. 1973, 3, 39-55. Available online: https: //www.sciencedirect.com/science/article/pii/0033589473900525 (accessed on 23 June 2021). [CrossRef]

30. Sanz-Pérez, E.; Pascual, C.; de Ojeda, L.S.; Menéndez-Pidal, I. La antigua laguna de Agreda. Celtiberia 2015, 109, $177-191$.

31. Sanz, E.; Pidal, I.M.; Escavy, J.; Ojeda, J. Hydrogeological Changes along a Fault Zone Caused by Earthquakes in the Moncayo Massif (Iberian Chain, Spain). Sustainability 2020, 12, 9034. [CrossRef]

32. Rushton, K.; Ward, C. The estimation of groundwater recharge. J. Hydrol. 1979, 41, 345-361. [CrossRef]

33. Sanz, E.; Pérez, J.; Menéndez-Pidal, I.; Meneses, J.M.; Molina, C.Y. Guía Geológica de la Sierra de Cabrejas y del Mo-Numento Natural de la Fuentona. Exma. Diputación Provincial de Soria, Soria, España. 150 págs. 2012. Available online: https: / / scholar.google.es/scholar (accessed on 23 June 2021). 
34. Catastro del Marques de la Ensenada 1749-1759. Available online: http:/ / pares.mcu.es/Catastro/servlets/ServletController? accion $=4 \&$ opcionV $=2$ (accessed on 23 June 2021).

35. Alcalde Olivares, M.C.; Gómez Manzaneque, F.; Postigo Mijarra, J.M.; Sanz Pérez, E.; Menéndez-Pidal, I. Pinus sylvestris L. en el Pleistoceno superior del Duero (Vega Cintora, Soria, España). Cuatern. Geomorfol. 2003, 17, 21-28.

36. Menéndez Amor, J. Análisis Palinológico de los Yacimientos Turbosos de Calatañazor (Soria). Estudios Geológicos, $31.795-797$. CSIC, Madrid, España. 1975. Available online: https://pascal-francis.inist.fr/vibad/index.php?action=getRecordDetail\&idt= PASCALGEODEBRGM7720087532 (accessed on 23 June 2021).

37. De Vaumas, E. Phénomènes Karstiques en Méditerranée Orientel; Ed. Rueda: Madrid, Spain, 1967; Volume 4, pp. $193-281$.

38. Gutiérrez, M.; Peña, J.L. Cordillera Ibérica. En: Geomorfología de España. Ed. Rueda; Geoforma Ediciones: Madrid, Spain, 1994; pp. 251-286.

39. Sese Benito, C. Mamíferos del Mioceno Medio de Escobosa de Calatañazor (Soria). Tesis Doctoral. Universidad Com-Plutense de Madrid. (Inédita). 1985. Available online: https://www.proquest.com/docview/1835821442?pq-origsite=gscholar\& fromopenview=true (accessed on 23 June 2021).

40. Monné, J.P. Geoarqueología aplicada a la reconstrucción paleoambiental: La evolución del Holoceno superior en el NE de España. Bol. Geol. Min. 2018, 1129, 285-303. [CrossRef]

41. Curl, R.L. Scallops and flutes.Transactions of the Cave. Res. Group Great Br. 1996, 7, 121-160. Available online: http://www. eauxsouterraines.eu/documents/articlessciences/Curl_1966.pdf (accessed on 23 June 2021).

42. Soligo, M.; Tuccimei, P.; Barberi, R.; Delitala, M.; Miccadei, E.; Taddeucci, A. U/Th dating of freshwater travertine from Middle Velino Valley (Central Italy): Paleoclimatic and geological implications. Palaeogeogr. Palaeoclim. Palaeoecol. 2002, 184, 147-161. [CrossRef]

43. Julian Andres, A.; Chueca Cia, J. Le Petit Âge Glaciaire Dans les Pyrénées Centrales Méridionales: Estimations des Paléotempératures à Partir D'inférences Géomorphologiques. Revue Géographique des Pyrénées et du Sud-Ouest. Sud-Ouest Européen, 3 ppp. 1998, pp. 79-88. Available online: https://www.persee.fr/doc/rgpso_1276-4930_1998_num_3_1_2697 (accessed on 23 June 2021).

44. Kresic, N.; Stevanovic, Z. Groundwater Hydrology of Springs: Engineering, Theory, Management, and Sustainability; Elsevier: Amsterdam, The Netherlands, 2010; p. 573.

45. White, W.B. Conceptual Models for Karstic Aquifers: Speleogenesis and Evolution of Karst Aquifers, v.1. p. 11-16. Proceedings of the Symposium Held February 24 through 27, 1999 Charlottesville, Virginia. Edited by Arthur N. Palmer, Margaret V. Palmer, and Ira D. Sasowsky. Karst Modelling, Karst Water Institute Special Publications. 2003. Available online: https: / / apps.dtic.mil/sti / pdfs / ADA369937.pdf\#page=19 (accessed on 23 June 2021).

46. Sáenz, C. Pico Frentes (Partes I a V). Celtiberia 1955, 9, 245-274.

47. Sáenz, C. La Fuente de La Toba y la Hidrología Local. Proyecto de Conducción de Aguas Potables de La Toba a Soria. Mapas y Anejos; Unpublished Report; Ayuntamiento de Soria: Soria, Spain, 1935; p. $59 . \quad$ Available online: https:/ / scholar.google.es/scholar?hl=es\&as_sdt=0\%2C5\&q=+Curl\%2CR.L.\%281966\%29.+Scallops+and+flutes.Transactions+ of+the+Cave.+Research+Group+of+Great+Britain $\% 2$ C+7+\%282\%29\%2C+121-60.\&btnG= (accessed on 23 June 2021). 